\title{
Mid-Cretaceous paleomagnetic results from Marie Byrd Land, West Antarctica: A test of post-100 Ma relative motion between East and West Antarctica
}

\author{
V. J. DiVenere and D. V. Kent \\ Lamont-Doherty Earth Observatory and Department of Geological Sciences, Columbia University, Palisades \\ New York
}

I. W. D. Dalziel

Institute for Geophysics, University of Texas at Austin

\begin{abstract}
As part of the tripartite, United States - United Kingdom - New Zealand, 1990-1991 South Pacific Rim International Tectonics Expedition, oriented samples were collected for paleomagnetic analysis from mid-Cretaceous (circa $100 \mathrm{Ma}$ ) intrusive rocks at sampling localities across $350 \mathrm{~km}$ of the Ruppert and Hobbs Coast area of Marie Byrd Land, West Antarctica. Paleomagnetic results are presented along with several lines of evidence, including a positive tilt test based on the attitude of circa 117 Ma volcanic rocks that the circa 100 Ma rocks intrude, which argue that these results are a representative estimate of the mid-Cretaceous magnetic field in Marie Byrd Land (MBL). The new circa $100 \mathrm{Ma}$ mean south pole $\left(224.1^{\circ} \mathrm{E} / 75.7^{\circ} \mathrm{S}, A_{95}=3.8^{\circ}\right.$, $N=19$ site means) is concordant with other West Antarctic results of similar age implying that at least Marie Byrd Land, Thurston Island and the Antarctic Peninsula have not experienced any paleomagnetically resolvable relative motion since the mid-Cretaceous. However, the poles from these Pacific-bordering blocks of West Antarctica are significantly offset from a synthetic apparent polar wander path that was produced for the East Antarctic craton, implying relative movement between East Antarctica and Pacific West Antarctica since about $100 \mathrm{Ma}$. Though the paleomagnetic estimate for east-west Antarctic relative motion may be reconciled with geologic estimates for extension in the Ross Sea at the extremes of the error envelope, the best paleomagnetic estimate of relative motion suggests a larger amount of total extension between East and West Antarctica (MBL) than previously suspected. Both estimates call for several hundreds of kilometers of post-100 Ma displacement between East Antarctica and the Pacific-bordering blocks of West Antarctica.
\end{abstract}

\section{Introduction}

Relative movements between the East Antarctic craton and West Antarctica have been discussed by many authors. It has long been known that East Antarctica is built on Precambrian basement, and more recently it has become apparent that West Antarctica is composed almost entirely of Phanerozoic crust which is divided into four major crustal blocks [Dalziel and Elliot, 1982]: Marie Byrd Land (MBL), Thurston Island (TI), the Antarctic Peninsula (AP), and the Ellsworth-Whitmore Mountains (EWM) (Figure 1). The overlap of AP with the Falklands Plateau in Gondwana reconstructions [e.g., Norton and Sclater, 1979] suggests that the peninsula must have experienced some relative motion with respect to East Antarctica since the inception of Gondwana breakup in the Jurassic. The pattern of thin crust in West Antarctica adjacent to the Transantarctic Mountains [Bentley, 1991] also suggests extension between East and West Antarctica. Finally, studies comparing Pacific plate hotspots with Atlantic hotspots have alternatively concluded that the hotspots moved with respect

Copyright 1994 by the American Geophysical Union.

Paper number 94JB00807. 0148-0227/94/94JB-00807\$05.00 to one another (assuming no East-West Antarctic relative motion) [Molnar and Stock, 1987] or that there must be a Cenozoic plate boundary somewhere between the north Pacific and East Antarctica (assuming that the hotspots are fixed with respect to one another) [Gordon and Cox, 1980; Duncan, 1981]. Marie Byrd Land is the crucial link connecting the Pacific plate with East Antarctica and the Atlantic bordering plates. This is because the spreading on the Pacific-Antarctic Ridge, which began in the Late Cretaceous, documents relative motion between the Pacific plate and MBL [Mayes et al., 1990], and any MBL-East Antarctic motion must be accounted for in order to compare Pacific plate motions with the Atlantic bordering plates.

Paleomagnetic studies from AP [Longshaw and Griffiths, 1983; Watts et al., 1984; Kellogg and Rowley, 1989; Grunow, 1993], EWM [Watts and Bramall, 1981; Grunow et al., 1987a], and TI [Grunow et al., 1987b; Grunow et al., 1991] have placed constraints on the position and relative motions of these blocks with respect to the East Antarctic craton. Middle Jurassic ( $175 \mathrm{Ma})$ paleomagnetic poles from AP and EWM are offset from the well-established Middle Jurassic pole from East Antarctica, supporting the idea of post-175 Ma relative motion between East and West Antarctica (at least AP and EWM). Grunow et al. [1991] proposed that this offset was due 


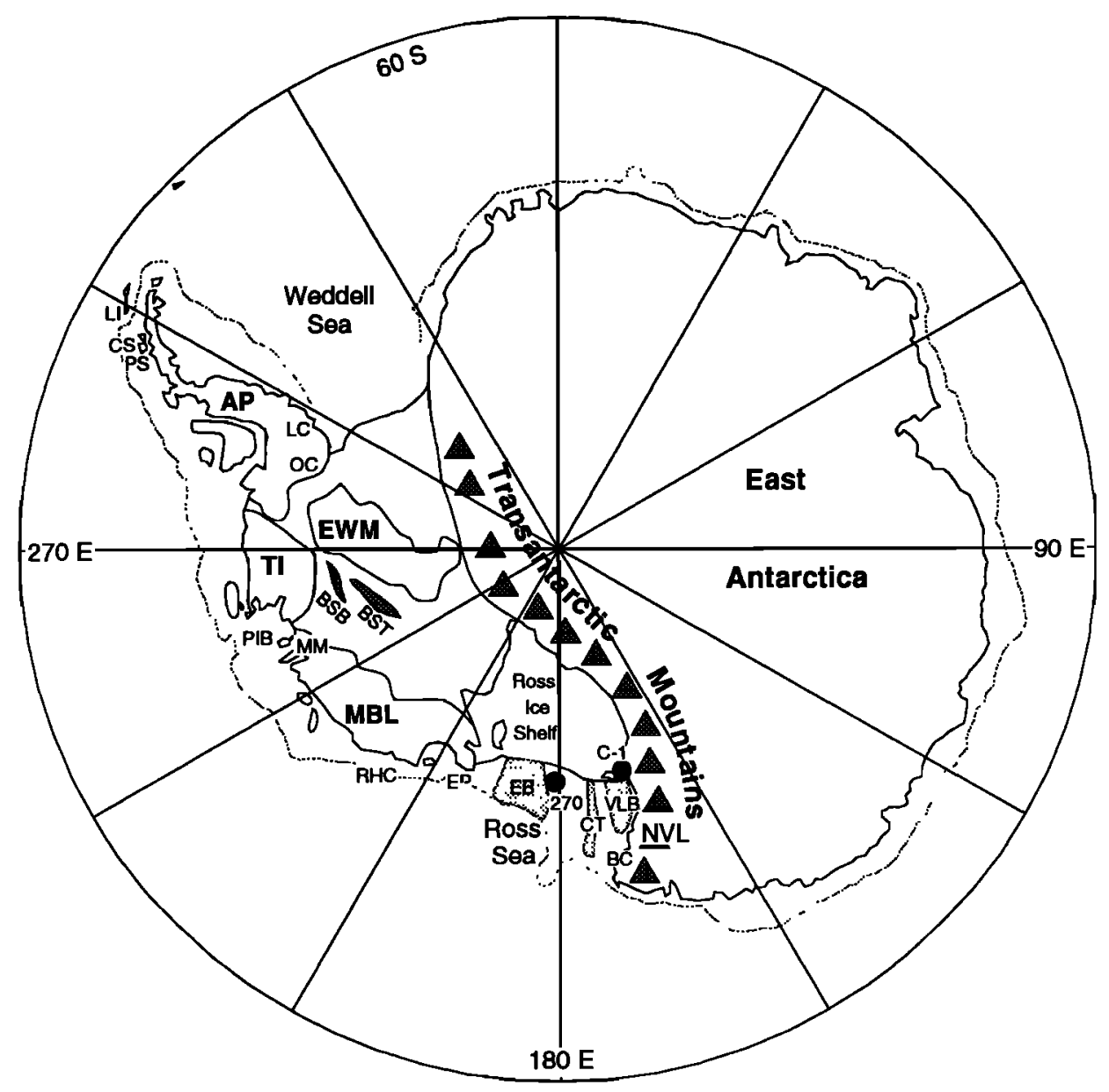

Figure 1. Antarctic location map: AP, Antarctic Peninsula; BC, Borchgrevink Coast; BSB, Byrd subglacial basin; BST, Bentley subglacial trough; C-1, CIROS-1 drill site; CS, Cape Spring; CT, Central Trough; EB, Eastern Basin; EP, Edward VII Peninsula; EWM, Ellsworth-Whitmore Mountains; LC, Lassiter Coast; LI, Livingston Island; MBL, Marie Byrd Land; MM, Mount Murphy; NVL, north Victoria Land; OC, Orville Coast; PIB, Pine Island Bay; PS, Penola Strait; RHC, Ruppert/Hobbs Coast study area; TI, Thurston Island; VLB, Victoria Land Basin; 270, DSDP Site 270.

to Jurassic opening in the Weddell Sea basin. It has been further suggested [Grunow, 1993] that the West Antarctic blocks rotated independently of each other between 175 and $110 \mathrm{Ma}$ but that there has been little or no motion with respect to East Antarctica since the mid-Cretaceous ( $-110 \mathrm{Ma})$.

The former position of MBL with respect to TI, AP, and EWM and also to East Antarctica is problematical on the basis of the two previously published paleomagnetic studies of Cretaceous rocks from MBL. Scharnberger and Scharon [1972] reported results from a small number of sites in igneous rocks with poor age control. They interpreted their results to indicate a low paleolatitude for MBL, discordant with the rest of Antarctica during the Cretaceous, suggesting that MBL was an exotic terrane. This contrasts with results from Grindley and Oliver [1983], who studied rhyolitic volcanics and mafic dike swarms, several of which were radiometrically dated at 90 $110 \mathrm{Ma}$. Their mean paleomagnetic pole implied a high paleolatitude for $\mathrm{MBL}$, consistent with a position adjacent, but with some displacement relative to East Antarctica since the mid-Cretaceous. Grunow et al. [1991] noted that this result would also imply relative motion between MBL and the remainder of West Antarctica.
New paleomagnetic results are presented from west central MBL which confirm a high-latitude mid-Cretaceous position for MBL adjacent to the East Antarctic craton. These results are concordant with mid-Cretaceous paleomagnetic results from TI and AP, implying no paleomagnetically resolvable relative motions between the Pacific-bordering blocks of West Antarctica (i.e., all of West Antarctica except EWM; see Figure 1) since the mid-Cretaceous. The West Antarctic midCretaceous paleomagnetic poles are compared with a newly constructed synthetic apparent polar wander path (APWP) for East Antarctica. The poles for MBL, TI, and AP are offset from the East Antarctic APWP, from which it may be concluded that the Pacific West Antarctic blocks have moved with respect to East Antarctica since about $100 \mathrm{Ma}$.

\section{Geologic Background}

The geologic history of western MBL begins with the deposition of a lower Paleozoic turbidite sequence, the Swanson Formation, which was folded and mildly metamorphosed in the Late Ordovician [Adams, 1986]. The Swanson Formation may be correlative with the Greenland Group of western South 


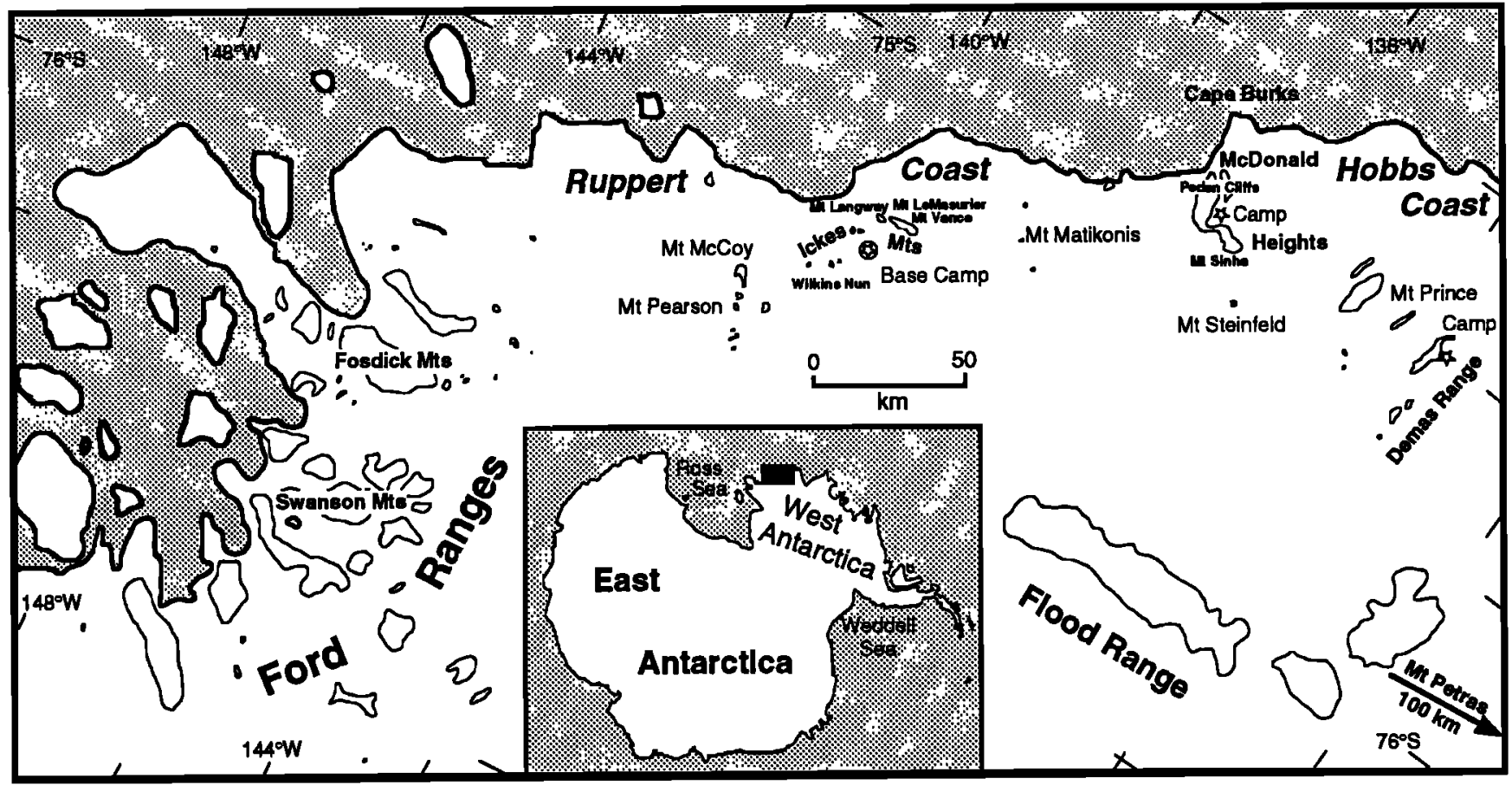

Figure 2. Map of study area, west central Marie Byrd Land.

Island, New Zealand, and similar turbidite sequences on the Campbell Plateau [Adams, 1986]. Bradshaw et al. [1983], while noting that the Swanson Formation had sedimentological similarities with the Robertson Bay Group of North Victoria Land bordering on the East Antarctic craton, do not consider them to necessarily be the same unit. In the Ford Ranges of western MBL (Figure 2), the Swanson Formation was intruded by the subduction-related, I-type, DevonianCarboniferous Ford Granodiorite, which may be correlative with similar Devonian igneous rocks in North Victoria Land (East Antarctica), Tasmania and Victoria (Australia), and South Island (New Zealand) [Adams, 1987; Grindley and Davey, 1982; Mason and Taylor, 1987]. Both the Swanson Formation and Ford Granodiorite are intruded by Upper Jurassic/Lower Cretaceous, I-type, Byrd Coast Granite in the Ford Ranges, where a younger, mid-Cretaceous pulse of magmatism is also detected [Adams, 1987]. Mid-Cretaceous granites from Edward VII Peninsula of westernmost MBL and midCretaceous alkali granites and syenites of the Ruppert and Hobbs Coast of west central Marie Byrd Land record A-type, rift related magmatism associated with the rifting of New Zealand/Campbell Plateau from the MBL margin [Spörli and Craddock, 1981; Weaver et al., 1992; Palais et al., 1993]. An erosional surface is overlain by upper Tertiary alkaline volcanic rocks [LeMasurier and Rex, 1983; LeMasurier and Rex, 1991]. The Tertiary volcanic rocks are interpreted to be related to a mantle plume [Hole and LeMasurier, 1994].

Most previous geochronologic studies in the region have been concentrated in the Ford Ranges of western MBL, including dating of the Swanson Formation, Ford Granodiorite, and Cretaceous Byrd Coast Granite [Boudette et al., 1966; Halpern, 1968; Wade and Wilbanks, 1972; Halpern, 1972; Adams, 1986; Adams, 1987]. Sparse geochronological work in central MBL (Ruppert-Hobbs Coast area) has suggested that the granitic rocks there may be correlative in age with the younger, mid-Cretaceous Byrd Coast Granites of the Ford Ranges and mid-Cretaceous granites of Edward VII Peninsula. Previously published $\mathrm{K}-\mathrm{Ar}$ ages for granitic rocks on the Ruppert Coast [Sporrli and Craddock, 1981] and dikes on the Ruppert-Hobbs Coast [Grindley and Oliver, 1983] cluster around $100 \mathrm{Ma}$.

Alkali granites and syenites are well represented in the Ruppert-Hobbs Coast (Figure 2). Sycnites are found throughout the Ickes Mountains and the McDonald Heights area. Alkali gabbros are found at Cape Burks and McDonald Heights. The units have been dated by the Rb-Sr (R. J. Pankhurst, personal communication, 1993) and zircon U-Pb and ${ }^{40} \mathrm{Ar} /{ }^{39} \mathrm{Ar}$ [Palais et al., 1993; D. G. Palais and S. B. Mukasa, personal communication, 1993] methods. Preliminary $\mathrm{Rb}-\mathrm{Sr}$ results for the McDonald Heights and Ickes Mountains syenites yield ages ranging from 95 to $99 \mathrm{Ma}$, while zircon $\mathrm{U}-\mathrm{Pb}$ ages range from 100 to $105 \mathrm{Ma}$, clustering at $102 \pm 2 \mathrm{Ma}$. Preliminary Rb-Sr results and zircon U-Pb results for the peralkaline granite at Wilkins Nunatak also give an age of about $100 \mathrm{Ma}$. Two ${ }^{40} \mathrm{Ar} /{ }^{39} \mathrm{Ar}$ results from biotite and hornblende separates from the alkaline gabbro at Cape Burks yield nearly identical plateau ages of $99 \pm 1 \mathrm{Ma}$. Preliminary $\mathrm{Rb}-\mathrm{Sr}$ ages for dike rocks at Mount Petras are about $100 \mathrm{Ma}$. The circa $100 \mathrm{Ma}$ syenites and alkali granites in the Ickes Mountains intrude bedded volcanic rocks with a preliminary $\mathrm{Rb}-\mathrm{Sr}$ age of about $117 \mathrm{Ma}$. The syenites at McDonald Heights intrude granodiorite with $\mathrm{Rb}-\mathrm{Sr}$ and zircon $\mathrm{U}-\mathrm{Pb}$ ages also of about $117 \mathrm{Ma}$.

\section{Sampling and Techniques}

As part of the paleomagnetic sampling during the 19901991 South Pacific Rim International Tectonics Expedition (SPRITE) field season in Marie Byrd Land, 204 oriented cores and 11 oriented hand samples were collected from 35 sites in 
circa $100 \mathrm{Ma}$ syenite, peralkaline granite, gabbro, and mafic dikes in the Ickes Mountains, McDonald Heights, and Mount Petras areas (Figure 2).

The cores were oriented with a magnetic compass and checked with a Sun compass at all sites where the outcrop was not in shadow. Magnetic declination was calculated for each site from the International Geomagnetic Reference Field [Langel, 1992] and appropriate corrections were applied to the field data. Differences between the magnetic and Sun compass were less than $2^{\circ}$ to $3^{\circ}$ for samples from most sites. In these cases the magnetic compass readings were used for the core orientations, since they were always available. Only at three very strongly magnetized sites in gabbro at Cape Burks were significant differences observed between the magnetic and Sun compass directions. At these sites the Sun compass readings were used.

All samples were subjected to either progressive thermal demagnetization up to $675^{\circ} \mathrm{C}$, or progressive alternating field (AF) demagnetization to maximum fields of $100 \mathrm{mT}$. Procedures and sample storage were performed in a magnetically shielded room with a nominal ambient field of $-250 \mathrm{nT}$. Thermal and alternating field demagnetizers are housed in their own mu-metal shields reducing the field in these to approximately $5 \mathrm{nT}$. Measurements were performed in a

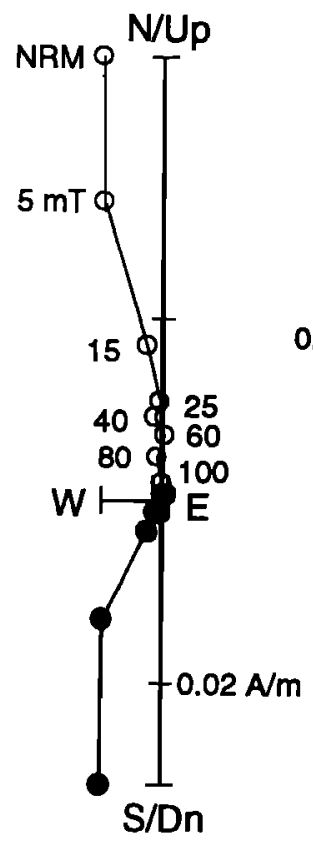

(a) Sample 1.1
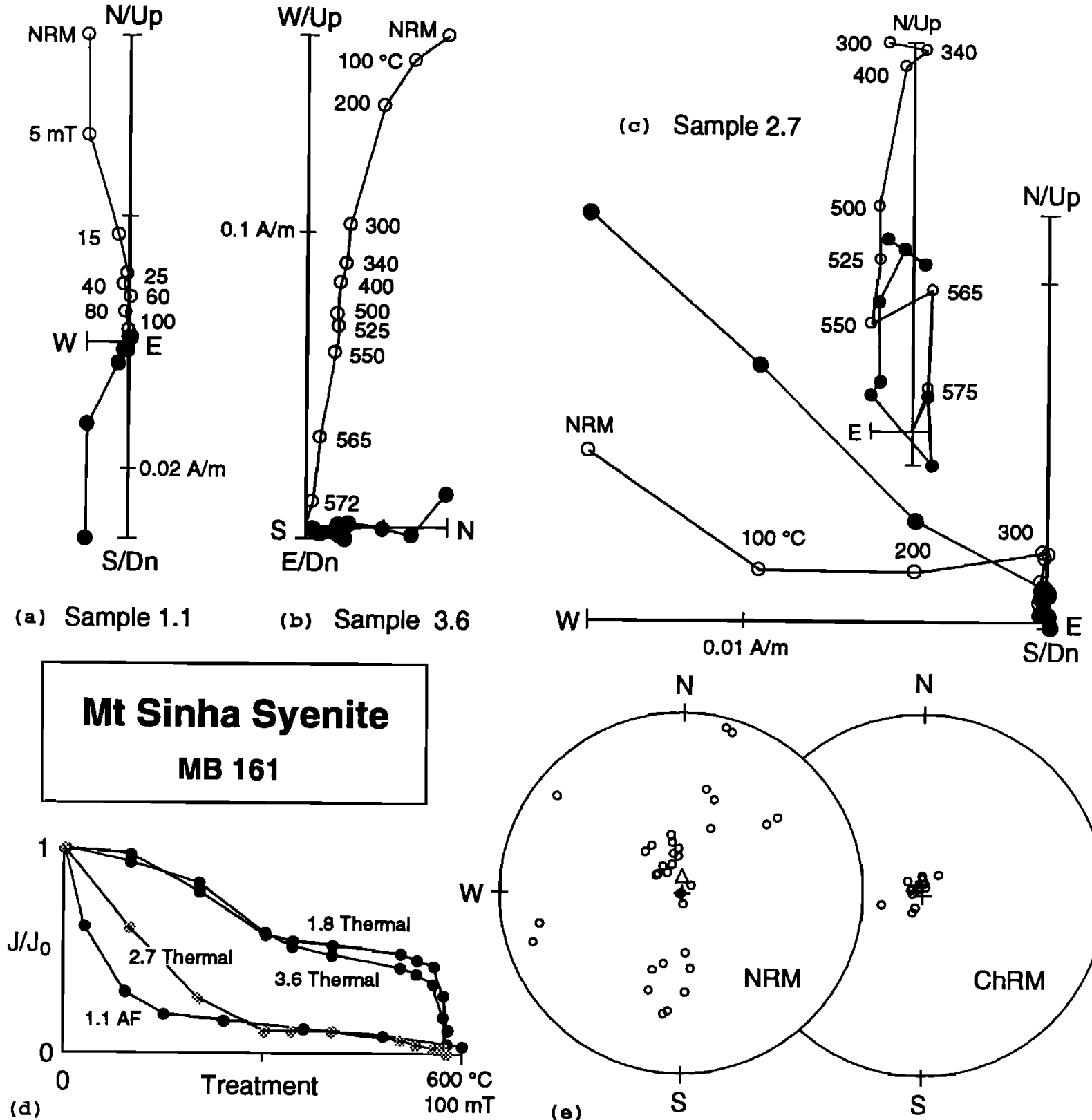

3.6
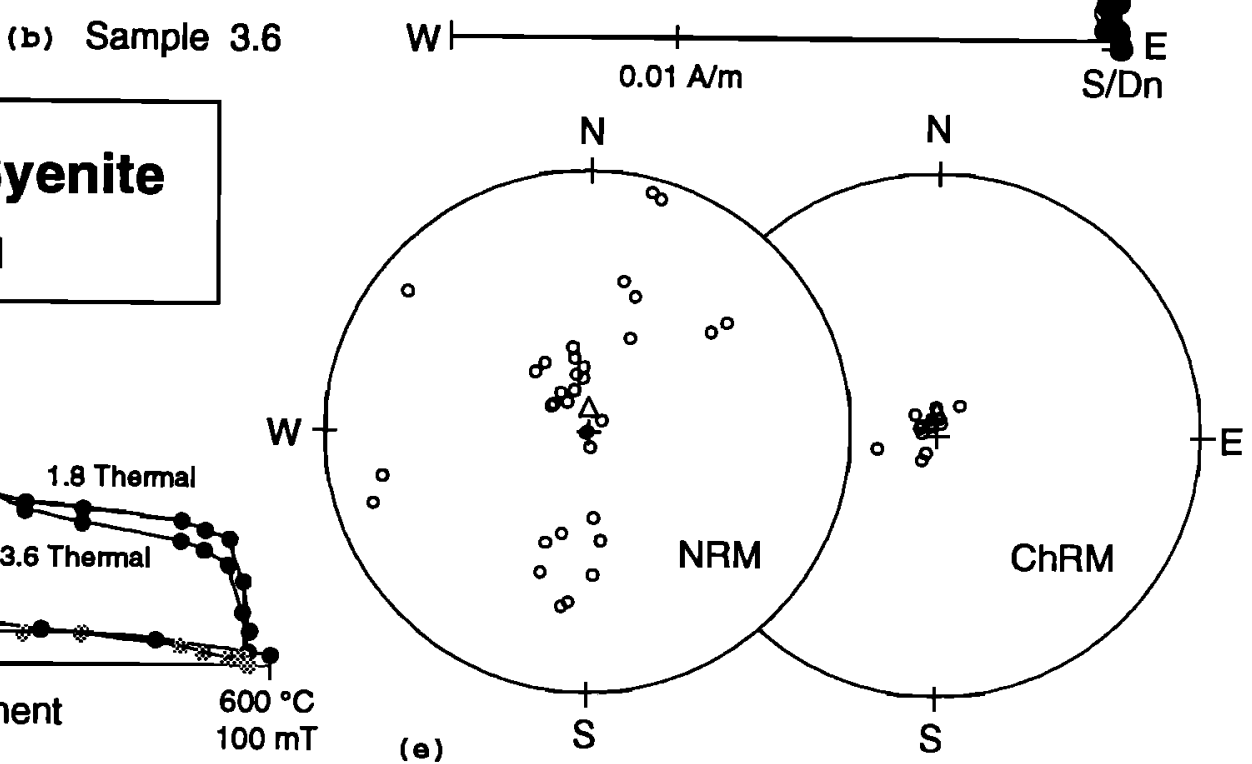

Figure 3. (a, b) Orthogonal plots of demagnetization data from Mount Sinha syenite, with open symbols representing the vertical trace and solid symbols the horizontal trace of the magnetization vector. (c) Samplc which was rejected with inset showing high temperature segment enlarged. (d) Remanent intensity (normalized to initial intensity) versus sample treatment. (e) Equal-area projection of sample NRM directions and ChRM component directions, with open symbols plotting on the upper hemisphere; triangle represents the time-averaged dipole field direction for this location. 
Superconducting Technologies two-axis cryogenic magnetometer, or a Digico spinner magnetometer for very strongly magnetized samples.

Component directions were determined via principal component analysis [Kirschvink, 1980] of linear segments chosen by eye from orthogonal plots [Zijderveld, 1967]. Components for approximately one-third of the samples, which had a greater degree of noise, were anchored to the origin. The principal component directions were plotted on equal-area nets and mean directions were determined by standard Fisher statistics [Fisher, 1953]. Virtual geomagnetic poles (VGPs) were calculated for each site and mean paleomagnetic poles and their associated confidence limits were calculated from these. All tests of significance between poles were made using the formal method of McFadden and Lowes [1981] at the $95 \%$ confidence level $(p=0.05)$. All confidence intervals cited in the text are $95 \%$ unless otherwise noted. For the graphical comparison of mean poles from different crustal blocks we plot $63 \%$ circles of confidence $\left(A_{63}\right)$ because they provide a good visual estimate of the similarity (simple overlap) or difference (no overlap) of mean poles [e.g., Irving and Irving, 1982].

\section{Paleomagnetic Results}

The circa $100 \mathrm{Ma}$ rocks in this study generally display similar demagnetization behavior. Variable, low-stability magnetizations are removed during $\mathrm{AF}$ and thermal demagnetization by 15 to $30 \mathrm{mT}$ or $250^{\circ}$ to $500^{\circ} \mathrm{C}$. Above these treatment levels, most samples have a stable characteristic remanent magnetization (ChRM) evident by linear decay to the origin on the orthogonal plots. The ChRM directions uniformly have steep negative inclination, indicating normal polarity. Maximum blocking temperatures around $580^{\circ} \mathrm{C}$ and moderate coercivities indicate magnetite as the principal remanence carrying mineral. This is consistent with reflected light microscopic inspection of polished sections of representative syenite and gabbro samples from McDonald Heights which showed igneous magnetite crystals with [111] ilmenite exsolution lamellae or coarse magnetite-ilmenite intergrowths, with lesser martite. Thermal and AF demagnetization yielded similar directions, but thermal demagnetization gave cleaner decay trajectories and therefore the majority of samples from each site were demagnetized thermally. Bulk magnetic susceptibility was monitored during thermal demagnetization experiments and the absence of major changes in susceptibility indicates that no significant alteration of magnetic mineralogy occurred during laboratory heating. Figures 3-8 illustrate demagnetization behavior and details are given for each sampling locale in the following sections.

\section{Results From McDonald Heights}

Mount Sinha (west) syenite. Nine oriented cores from each of three sites were collected in variably weathered syenite from a nunatak just west of Mount Sinha (Figure 3). The average natural remanent magnetization (NRM) intensity is $0.1 \mathrm{~A} / \mathrm{m}$ and the directions are scattered with negative inclinations (Figure 3e). A stable ChRM was isolated in four of nine samples from site 1 , only one sample from site 2 , and all nine samples from site 3 (Figures $3 a$ and $3 b$ ). The stable samples have a discrete unblocking temperature range between

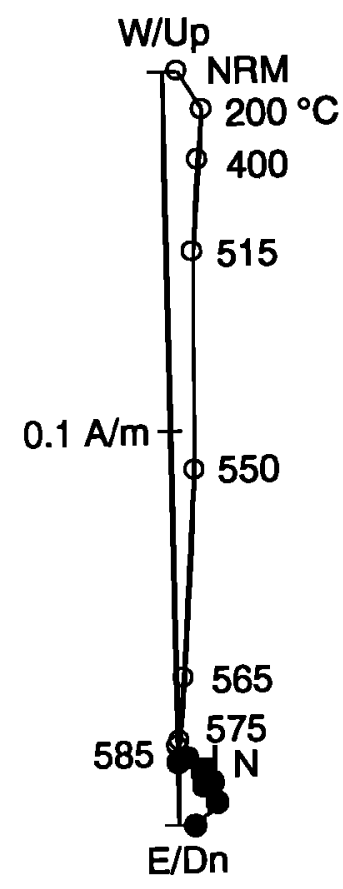

(a) Sample 1.5t

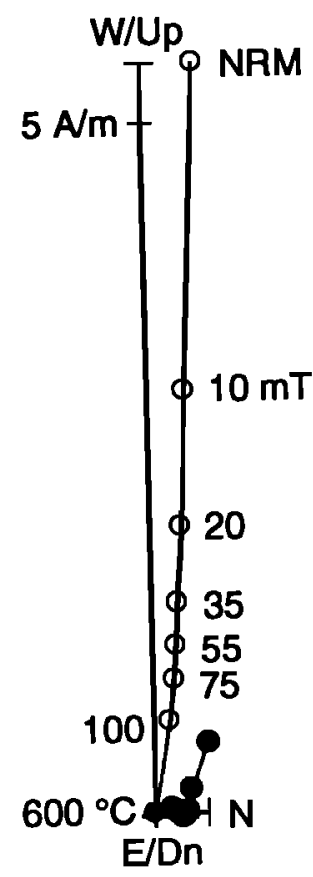

(b) Sample 2.7

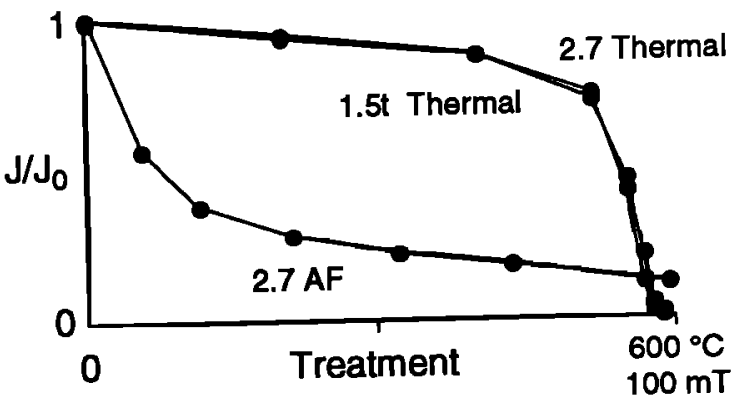

(c)

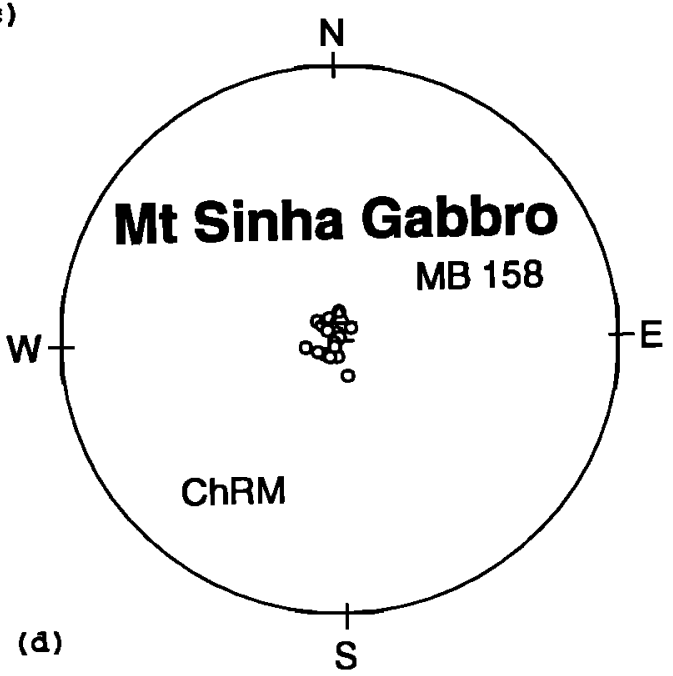

Figure 4. (a, b) Orthogonal plots of demagnetization data from Mount Sinha gabbro. (c) Intensity versus sample treatment. (d) Equal-area projection of ChRM component directions; all symbols defined as in Figure 3. 
Table 1. Site Mean Directions and South Paleomagnetic Poles

\begin{tabular}{|c|c|c|c|c|c|c|c|c|c|c|}
\hline \multirow[b]{3}{*}{ Site } & \multirow[b]{3}{*}{$n / N$} & \multirow[b]{3}{*}{$k$} & \multirow[b]{3}{*}{$a_{95}$} & \multicolumn{4}{|c|}{ Directions } & \multicolumn{3}{|c|}{ Pole } \\
\hline & & & & \multicolumn{2}{|c|}{ In Situ } & \multicolumn{2}{|c|}{ Tilt Corrected } & \multirow[b]{2}{*}{ Plon ${ }^{\circ} \mathrm{E}$} & \multirow[b]{2}{*}{ Plat ${ }^{\circ} \mathrm{N}$} & \multirow[b]{2}{*}{$A_{95}$} \\
\hline & & & & D & I & D & I & & & \\
\hline \multicolumn{2}{|c|}{ Mount Sinha Syenite, } & \multicolumn{6}{|c|}{ McDonald Heights, Longitude/Latitude: 223.80/-75.07 } & \multicolumn{2}{|c|}{ In Situ Pole } & \\
\hline MB 161.1 & $4 / 9$ & 268 & 5.6 & 236.3 & -85.0 & & & 246.2 & -68.0 & \\
\hline MB $161.2^{a}$ & $1 / 9$ & & & 23.2 & -86.2 & & & 203.3 & -82.4 & \\
\hline MB 161.3 & $9 / 9$ & 108 & 5.0 & 327.7 & -84.9 & & & 264.8 & -81.7 & \\
\hline Mean & $2 / 3$ & & & 282.6 & -86.5 & & & 251.3 & -75.0 & \\
\hline \multicolumn{2}{|c|}{ Mount Sinha Gabbro, } & \multicolumn{6}{|c|}{ McDonald Heights, Longitude/Latitude: 223.85/-75.07 } & \multicolumn{2}{|c|}{ In Situ Pole } & \\
\hline MB 158.1 & $7 / 7$ & 560 & 2.6 & 329.2 & -85.1 & & & 261.7 & -81.8 & \\
\hline MB 158.2 & $6 / 7$ & 241 & 4.3 & 304.7 & -86.9 & & & 247.8 & -77.5 & \\
\hline MB158.3 & $7 / 7$ & 409 & 3.0 & 206.8 & -85.1 & & & 234.7 & -65.9 & \\
\hline Mean & $3 / 3$ & 336 & 6.7 & 282.4 & -87.5 & & & 243.4 & -75.3 & 13.5 \\
\hline Peden Cliffs & Syenite, $N$ & McDona & d Heigl & Longitu & de/Latitu & : 223.48/ & -74.95 & Tilt Corre & cted Pole & \\
\hline MB 160.1 & $3 / 6$ & 253 & 7.8 & 108.9 & -86.4 & & & 201.7 & -71.3 & \\
\hline MB 160.2 & $4 / 7$ & 89 & 9.7 & 92.6 & -83.9 & & & 184.9 & -70.3 & \\
\hline MB160.3 & $4 / 7$ & 55 & 12.5 & 75.5 & -82.5 & & & 170.9 & -71.8 & \\
\hline MB 160.4 & $5 / 7$ & 78 & 8.7 & 6.4 & -86.2 & & & 217.2 & -82.3 & \\
\hline MB160.5 & $9 / 11$ & 323 & 2.9 & 56.3 & -87.8 & & & 207.4 & -76.9 & \\
\hline MB 160.6 & $5 / 5$ & 125 & 6.9 & 76.8 & -84.3 & & & 181.6 & -73.5 & \\
\hline Mean & $6 / 6$ & 656 & 2.6 & 74.7 & -85.8 & & & 190.7 & -74.8 & 5.2 \\
\hline A comp & 38 & 30 & 4.3 & 29.5 & -66.0 & & & 85.4 & -60.6 & \\
\hline Mount Vance & Syenite, & Ickes $M$ & ountain & Longitud & e/Latitud & $220.60 /-7$ & 75.40 & Tilt Corre & cted Pole & \\
\hline MB223.1 & $7 / 7$ & 68 & 7.4 & 1.3 & -73.3 & 8.6 & -88.2 & 217.8 & -78.9 & \\
\hline MB223.2 & $7 / 7$ & 210 & 4.2 & 348.5 & -74.0 & 283.4 & -86.7 & 247.2 & -75.5 & \\
\hline MB 223.3 & $7 / 7$ & 224 & 4.0 & 348.0 & -72.0 & 306.1 & -85.4 & 259.8 & -78.2 & \\
\hline Mean & $3 / 3$ & 1133 & 3.7 & 352.5 & -73.2 & 308.3 & -87.2 & 242.6 & -78.1 & 7.2 \\
\hline Mount Langw & vay Syeni & ite, Ickes & Moun & $s$, Longi & ude/Lat & e: 220.2 & $2 /-75.48$ & Tilt Corre & cted Pole & \\
\hline MB305.1 & $3 / 3$ & 283 & 7.3 & 336.4 & -76.0 & 250.9 & -84.0 & 252.3 & -68.5 & \\
\hline MB305.2 & $7 / 7$ & 312 & 3.4 & 353.2 & -76.4 & 230.6 & -87.8 & 231.4 & -72.4 & \\
\hline MB305.3 & $9 / 9$ & 302 & 3.0 & 344.8 & -78.1 & 223.6 & -85.4 & 237.3 & -67.9 & \\
\hline Mean & $3 / 3$ & 1299 & 3.4 & 344.7 & -76.9 & 237.6 & -85.8 & 240.8 & -69.8 & 6.8 \\
\hline Mount Petras & Intrusior & ns, Lon & itude/L & ude: 231 & $.40 /-75$ & & & In Situ & Pole & \\
\hline MB224 $4^{b}$ & $3 / 3^{d}$ & 325 & 6.8 & 149.4 & -84.3 & & & 217.5 & -65.5 & \\
\hline $\mathrm{MB}^{225^{a}}$ & $3 / 3^{d}$ & 183 & 9.1 & 57.2 & -86.5 & & & 202.4 & -78.2 & \\
\hline Mean & $2 / 2$ & & & 117.2 & -86.7 & & & 212.5 & -72.0 & \\
\hline Wilkins Nunat & tak Gran & ite, Lon & itude/L & tude: 22 & $0.05 /-75$ & & & In Situ & Pole & \\
\hline MB302.123 & $3 / 3^{d}$ & 47 & 18.2 & 342.5 & -81.9 & & & 317.5 & -85.1 & \\
\hline MB302.4 & $5 / 6$ & 584 & 3.2 & 349.3 & -80.6 & & & 358.0 & -85.0 & \\
\hline MB302.5 & $5 / 7$ & 356 & 4.1 & 336.9 & -79.1 & & & 342.5 & -80.4 & \\
\hline MB302.6 & $5 / 6$ & 379 & 3.9 & 329.6 & -81.1 & & & 315.1 & -81.3 & \\
\hline MB302.7 & $5 / 6$ & 175 & 5.8 & 343.3 & -81.8 & & & 324.1 & -85.3 & \\
\hline MB302.8 & $2 / 2^{d}$ & & & 343.3 & -80.4 & & & 344.7 & -83.8 & \\
\hline Mean & $6 / 6$ & 2939 & 1.2 & 340.7 & -80.9 & & & 333.4 & -83.7 & 2.3 \\
\hline Cape Burks G & Fabbro, $L$ & ongitud & Latituo & $223.13 \%$ & 74.77 & & & In Situ & Pole & \\
\hline MB202.1 & $6 / 6$ & 82 & 7.5 & 142.3 & -76.0 & 234.0 & -33.3 & 197.8 & -50.4 & \\
\hline MB202.2 & $7 / 7$ & 244 & 3.9 & 171.6 & -74.8 & 233.3 & -25.9 & 217.3 & -46.4 & \\
\hline MB202.3 & $7 / 7$ & 152 & 4.9 & 152.2 & -73.9 & 231.3 & -30.9 & 203.5 & -46.0 & \\
\hline MB202.4 & $5 / 5$ & 298 & 4.4 & 168.7 & -75.1 & 233.5 & -26.7 & 215.4 & -47.0 & \\
\hline MB202.5 & $6 / 6$ & 948 & 2.2 & 174.9 & -73.9 & 232.9 & -24.7 & 219.5 & -44.8 & \\
\hline MB202.6 & $5 / 5$ & 712 & 2.9 & 171.3 & -76.2 & 234.8 & -26.4 & 217.3 & -48.7 & \\
\hline MB202.7 & $5 / 5$ & 209 & 5.3 & 194.3 & -61.7 & 173.1 & -31.7 & 235.0 & -28.0 & \\
\hline MB202.9 & $7 / 7$ & 386 & 3.1 & 174.6 & -55.5 & 164.9 & -22.3 & 218.5 & -20.9 & \\
\hline Mean & $8 / 9$ & 76 & 6.4 & 171.7 & -71.5 & & & 216.5 & -42.1 & 9.4 \\
\hline
\end{tabular}

Circa 100 Ma Mean Pole (Vance, Langway, Sinha syenite and gabbro, Peden Cliffs, and Mount Petras) $19 / 20 \quad 79$

$\begin{array}{lll}224.1 & -75.7 & 3.8\end{array}$

Abbreviations: $n / N$, number of samples accepted / number collected for site means or number of sites accepted over number of sites collected for group means; $k$, Fisher's precision parameter; $a_{95}$, radius of $95 \%$ cone of confidence about mean direction; directions, $D$, mean declination; $I$, mean inclination; pole, Plon, mean paleomagnetic pole east longitude; Plat, mean paleomagnetic pole north latitude (negative is south latitude); $A_{95}$, radius of $95 \%$ cone of confidence about mean pole.

a Only one stable sample; site not used in further calculations. $\quad c$ Porphyry.

$b$ Mafic Dike. $\quad d$ Hand samples. 

grouped (Figure 3e). grouped (Figure 4d). field $(D=71.9, D=-75.1)$. See Table 1 .

about $550^{\circ}$ and $580^{\circ} \mathrm{C}$ over which the remaining magnetization decays to zero (samples 1.8 and 3.6 in Figure 3d). The remainder of the samples did not yield stable decay trajectories and only a small portion of the NRM remained by $300^{\circ} \mathrm{C}$ (sample 2.7 in Figures $3 c$ and 3d). The stable ChRMs are well

Mount Sinha gabbro. Seven oriented cores were collected from each of three sites in a gabbroic member near the contact with the intruded Lower Cretaceous granodiorites on the north flank of Mount Sinha (Figure 4). NRM intensity is strong, with an average of $4 \mathrm{~A} / \mathrm{m}$. NRM directions are nearly vertical upward and well grouped. Alternating field demagnetization shows a hard magnetization which is usually not completely demagnetized by $100 \mathrm{mT}$, while thermal demagnetization shows that the NRM is little affected below about $500^{\circ} \mathrm{C}$ (Figures $4 \mathrm{a}, 4 \mathrm{~b}$, and $4 \mathrm{c}$ ). The ChRM directions are well

The mean direction calculated from the two stable Mount Sinha syenite site means (declination $(D)=282.6$, inclination $(I)=-86.5, N=2)$ is nearly identical to the mean direction calculated from the three gabbro site means $(D=282.4, I=-87.5$, $a_{95}=6.7^{\circ}$ ). Both are significantly different from the time-averaged axial dipole field $(D=0, I=-82.4)$ and the present-day

Peden Cliffs syenite. A total of 43 oriented cores was collected from six sites in syenite and microdiorite inclusions at Peden Cliffs (Figure 5). The average NRM intensity is 0.1 $\mathrm{A} / \mathrm{m}$. A consistent break is seen in the demagnetization trajectory of most samples at around 10 to $20 \mathrm{mT}$ during AF treatment and around $300^{\circ} \mathrm{C}$ during thermal demagnetization (Figures 5a and 5b). The lower stability component is northeasterly with intermediate to steep inclination. The low-sta-

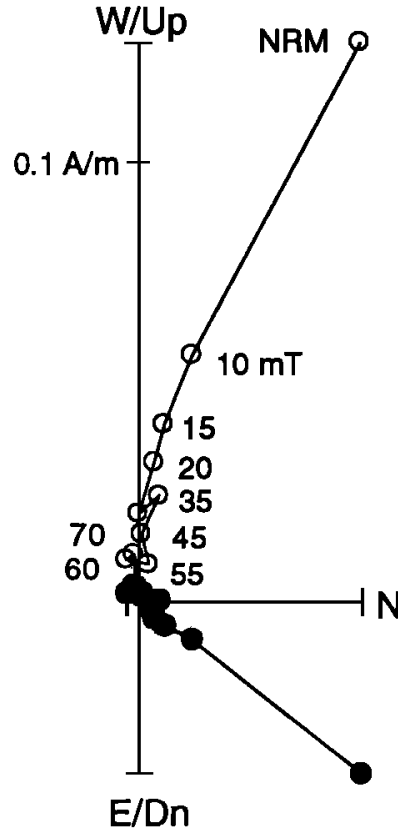

(a) Sample 2.4

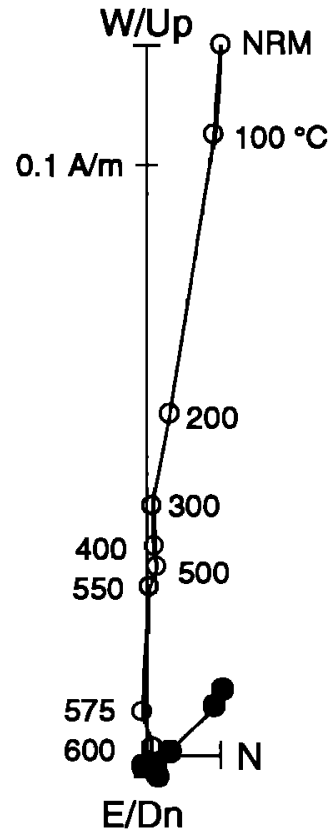

(b) Sample 5.9 bility component, with a mean direction calculated at $D=$ 29.5, $I=-66.0$, and $a_{95}=4.3^{\circ}$, is significantly different from the high-stability component, axial dipole field direction and present-day field direction. Given its low stability and dissimilarity to other directions, the low-stability component is likely to have been acquired during sample collection or preparation. The grouping is probably due to the fact that all samples were collected along a single cliff face and therefore have very similar core orientations. The ChRM remaining after the removal of the low-stability magnetization is well grouped about an easterly and nearly vertical, direction, similar to the Mount Sinha ChRM directions (Figure 5d). The mean direction calculated from the six site mean directions $(D=74.7, I=$ $-85.8, a_{95}=2.6^{\circ}$ ) (Table 1) is significantly different from both the axial dipole field $(D=0, I=-82.3)$ and the present-day field $(D=71.8, I=-75.2)$.

\section{Paleomagnetic Results From the Ickes Mountains}

Mount Vance syenite. Seven oriented cores from each of three sites were collected from the syenite at the base of Mount Vance in the Ickes Mountains (Figure 6). The syenite intrudes gently dipping, Lower Cretaceous bedded volcanic rocks. The average NRM intensity is $0.3 \mathrm{~A} / \mathrm{m}$. The ChRM is usually not completely demagnetized by $100 \mathrm{mT}$ (Figures $6 \mathrm{a}$ and $6 \mathrm{c}$ ). Maximum unblocking temperatures (Figure $6 \mathrm{~b}$ and 6c) and Curie temperatures appear to be slightly elevated $\left(585^{\circ}\right.$ to $600^{\circ} \mathrm{C}$ ) above those expected for pure magnetite (about $575^{\circ}$ to $580^{\circ} \mathrm{C}$ ), suggesting a non stoichiometric magnetite or possibly a low titanium ilmenohematite rather than pure magnetite as the remanence carrying mineral.

Mount Langway syenite. Nineteen oriented cores
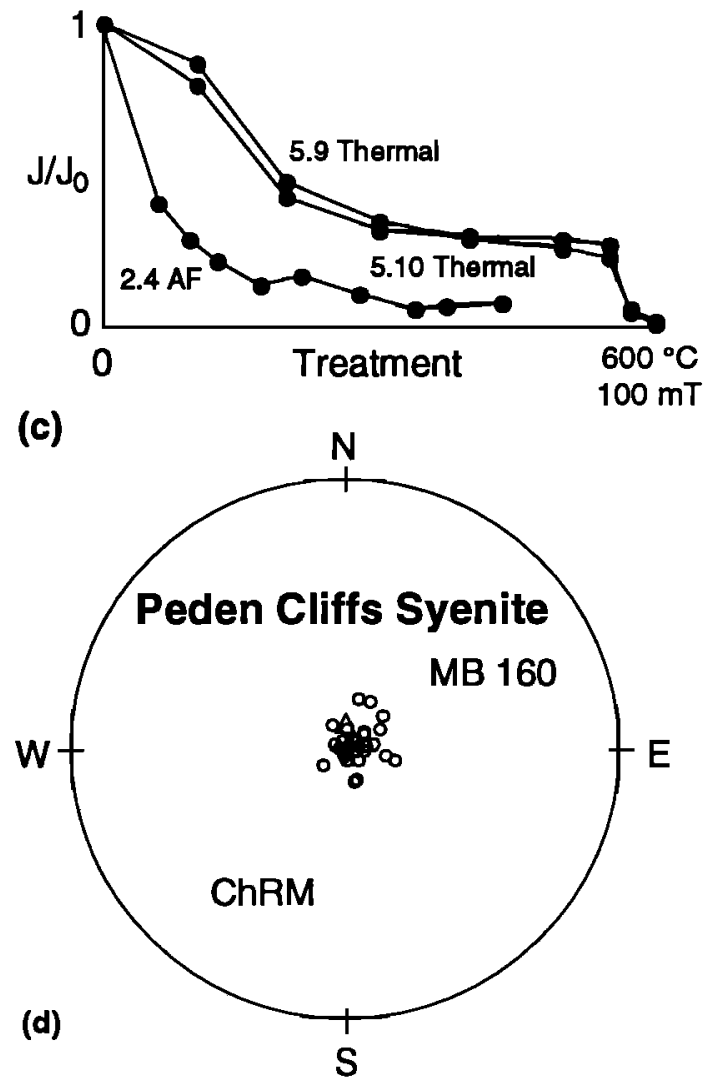

Figure 5. (a, b) Orthogonal plots of demagnetization data from Peden Cliffs syenite. (c) Intensity versus treatment. (d) Equal-area projection of ChRM directions; all symbols defined as in Figure 3. 


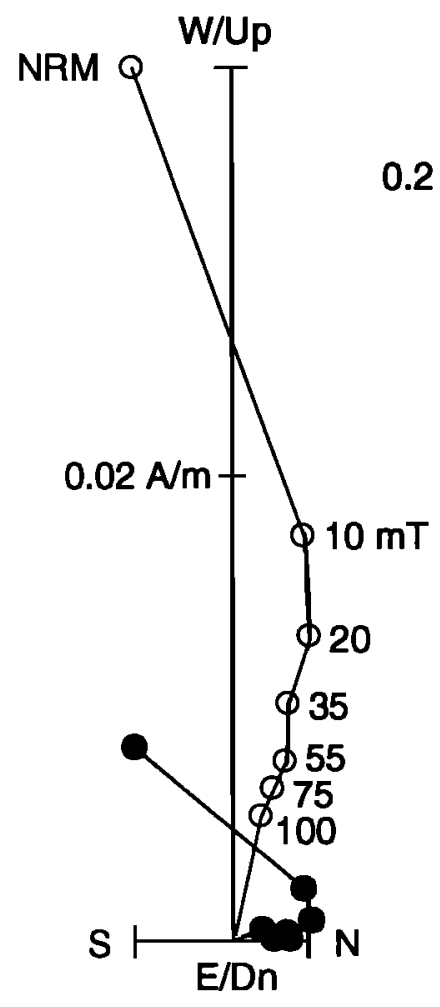

(a) Sample 3.1

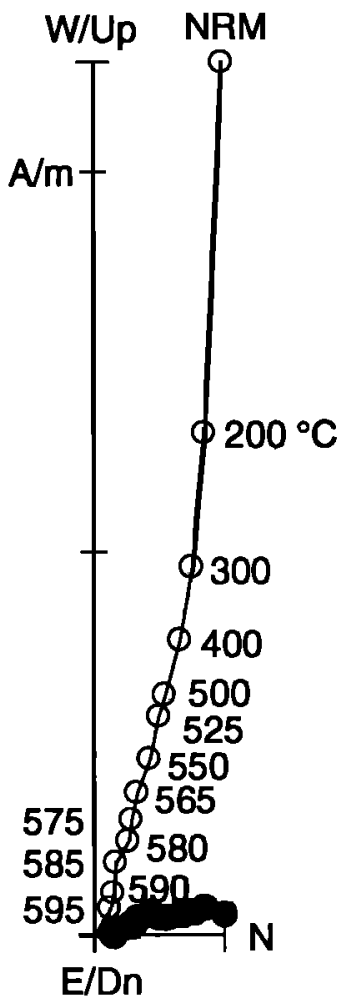

(b) Sample 3.3t
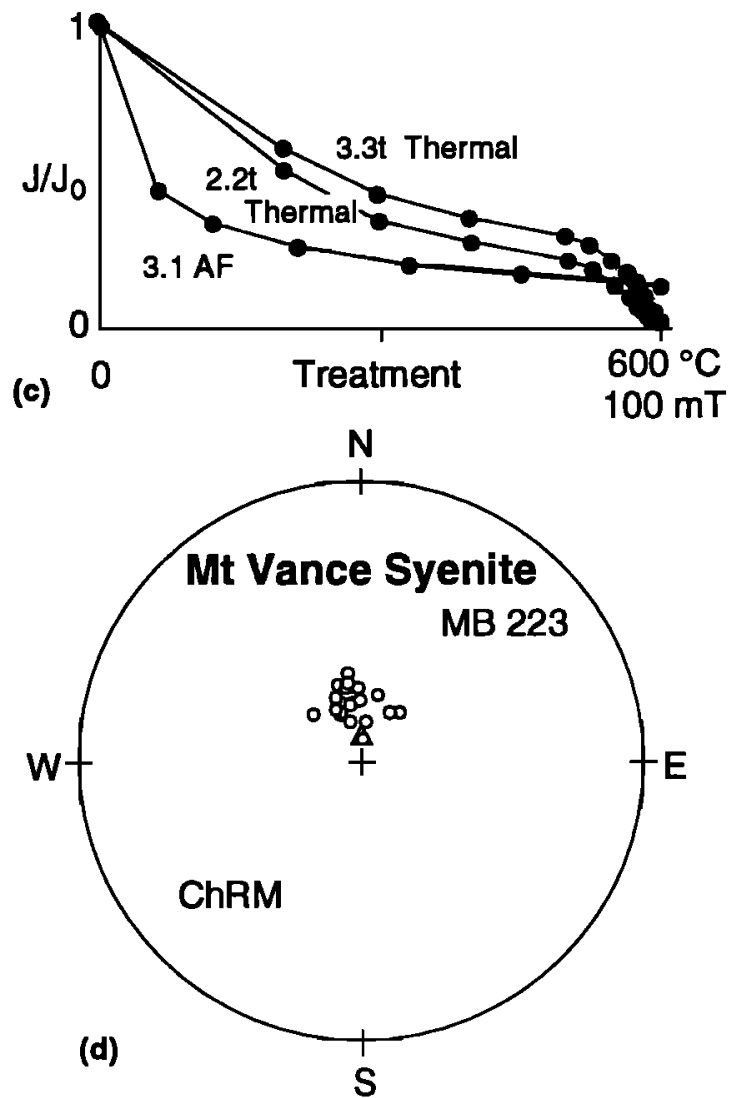

Figure 6. (a, b) Orthogonal plots of demagnetization data from Mount Vance syenite. (c) Intensity versus sample treatment. (d) Equal-area projection of in situ ChRM component directions; all symbols defined as in Figure 3.

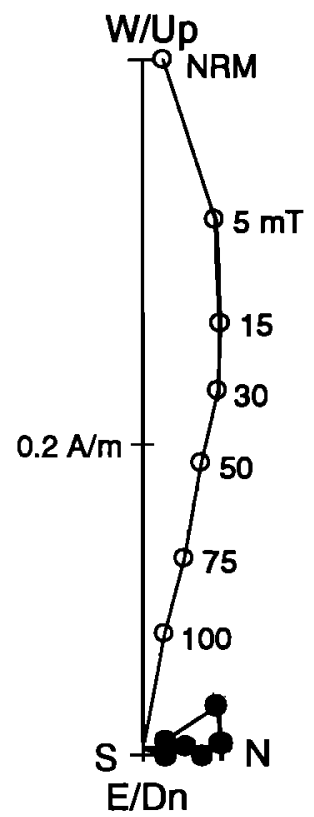

(a) Sample 2.3

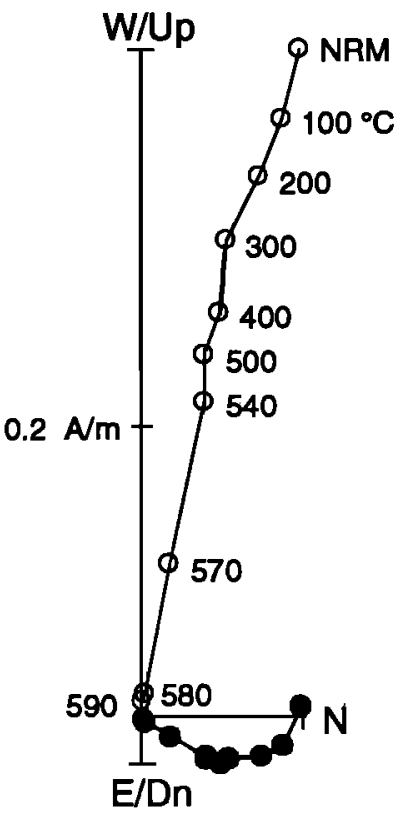

(b) Sample 2.6

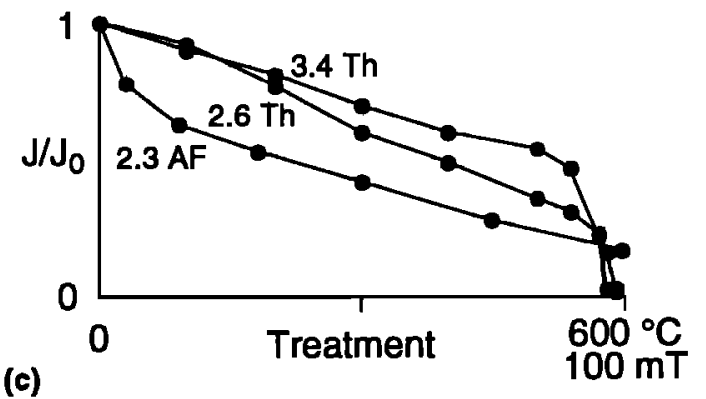

(c)

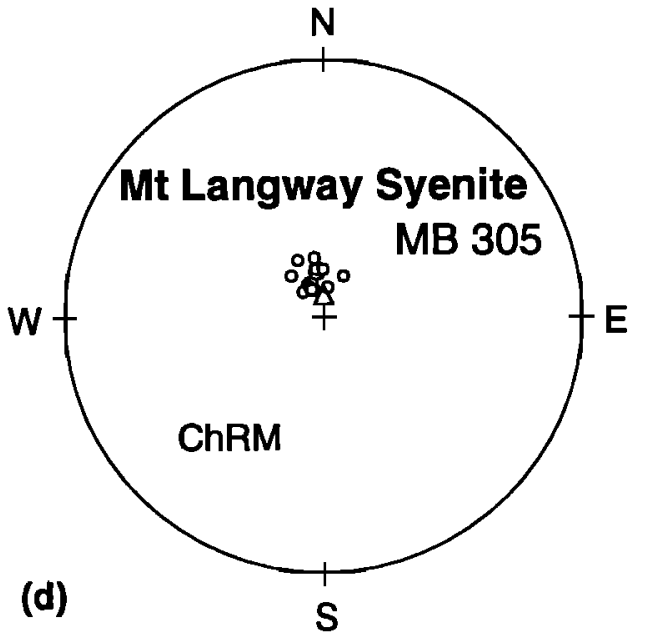

Figure 7. (a, b) Orthogonal plots of demagnetization data from Mount Langway syenite. (c) Intensity versus sample treatment (d) Equal-area projection of in situ ChRM component directions; all symbols defined as in Figure 3. 
were collected at three sites from the syenite at Mount Langway, $5 \mathrm{~km}$ from Mount Vance (Figure 7). The average NRM intensity is $0.2 \mathrm{~A} / \mathrm{m}$. Demagnetization trajectories are very similar to those from Mount Vance but maximum blocking temperatures are about $580{ }^{\circ} \mathrm{C}$ (Figures $7 \mathrm{a}, 7 \mathrm{~b}$, and 7c) suggesting magnetite as the remanence carrying mineral.

The in situ mean direction calculated from the three Mount Vance syenite site mean directions $\left(D=352.5, I=-73.2, a_{95}=\right.$ $\left.3.7^{\circ}\right)$ is not significantly different from the in situ mean direction from the three Mount Langway syenite site means $(D=$ $344.7, I=-76.9, a_{95}=3.4^{\circ}$ ). They are significantly different from both the axial dipole $(D=0, I=-82.6)$ and the presentday field $(D=75.3, I=-75.7)$. These results are broadly similar to paleomagnetic results of Grindley and Oliver [1983] from Mount Vance and Mount Langway which have northwesterly declinations and steep negative inclinations (a mean direction calculated from their results is $D=327.7, I=-73.0, N$ $=2$ ).

\section{Other Circa 100 Ma Paleomagnetlc Results}

Mount Petras Intrusions. At Mount Petras, $250 \mathrm{~km}$ SE of McDonald Heights, three oriented hand samples were taken from a mafic dike intruding an intrusive porphyry on the southwest spur (MB224), and another three were collected from the porphyry on the southeast spur (MB225). Two or three specimens per block were subjected to AF demagnetization and one specimen per block to thermal demagnetization (Figures 8a - 8d). All specimens yielded a stable ChRM

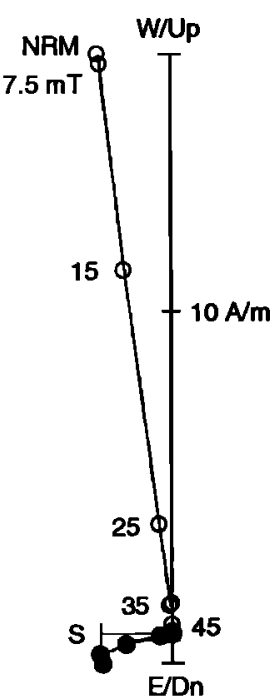

(a) MB 224.1.4

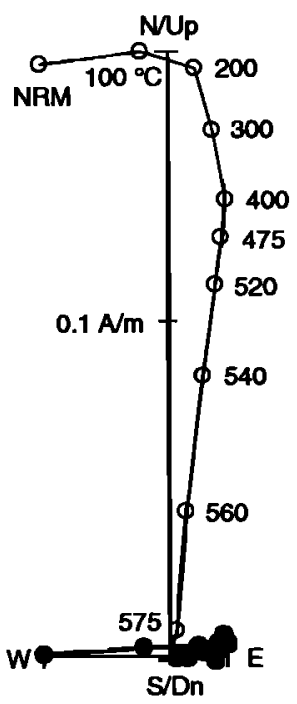

(b) MB 225.2.2

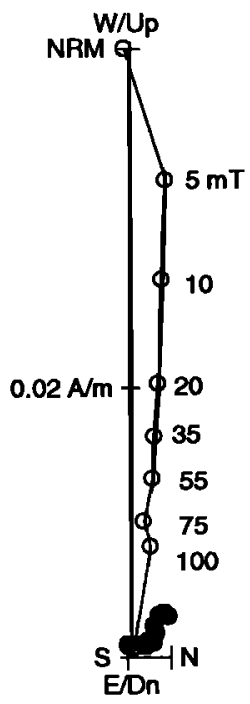

(๑) MB 302.6.3

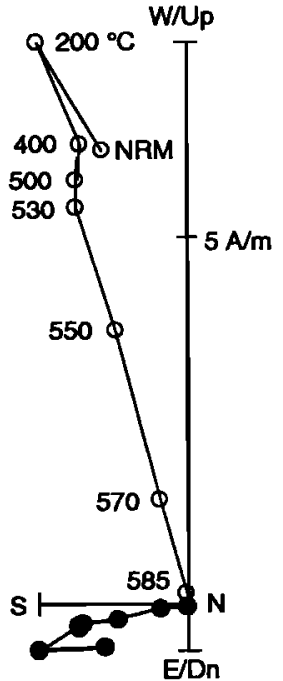

(b) MB 202.5.4

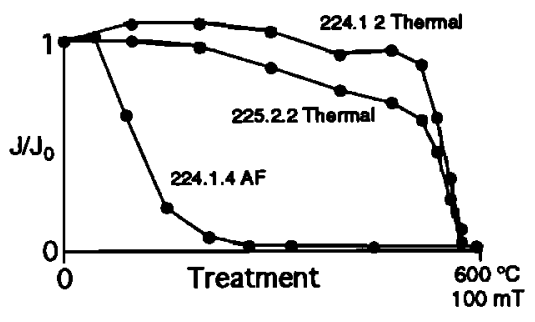

(c)

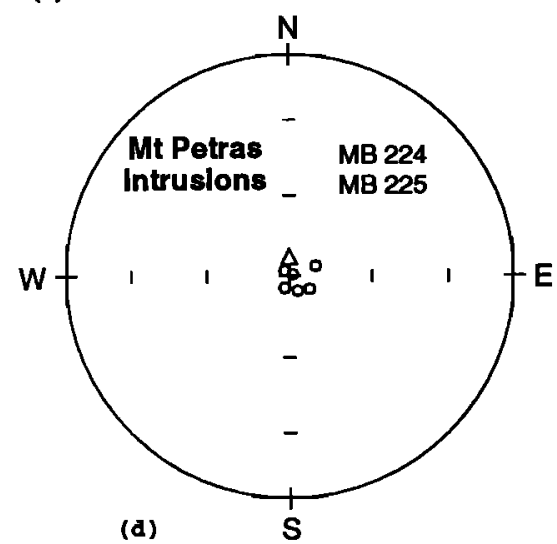

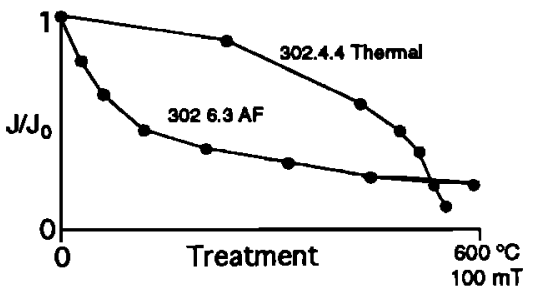

(1)

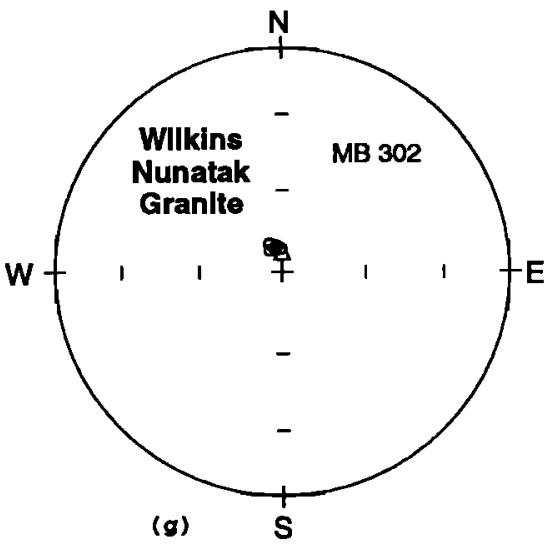

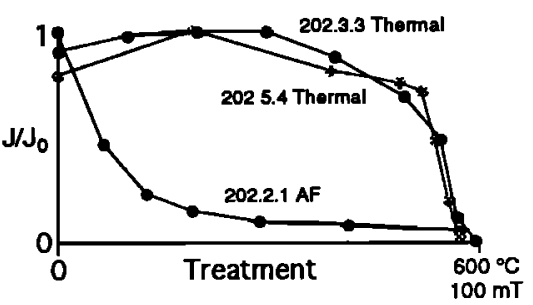

(I)

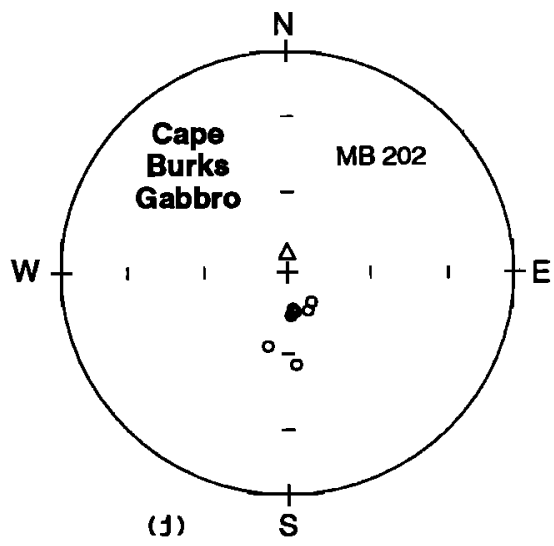

Figure 8. Demagnetization data from (a) - (d) Mount Petras intrusions, (e) - (g) Wilkins Nunatak granite, and (h) - (j) Cape Burks gabbro; all symbols defined as in Figure 3. 
(Figures 8a and 8b). The mean direction is $D=117.2, I=$ -86.7 , for $N=2$ site means $\left(D=117.2, I=-86.7, a_{95}=5.0^{\circ}\right.$ for $N=6$ block means). Grindley and Oliver [1983] reported results from six sites (one or two blocks per site) from rhyodacite flows at Mount Petras citing K-Ar plagioclase and hornblende ages ranging from 81 to $104 \mathrm{Ma}$. A mean direction calculated from their 6 site mean directions $(D=214.0, I=-75.0$, $\left.a_{95}=8^{\circ}\right)$ is significantly different from our Mount Petras intrusions result.

Wilkins Nunatak granite. Twenty-five oriented cores and 5 oriented hand samples were taken from six sites in peralkaline granite at Wilkins nunatak, approximately $15 \mathrm{~km}$ south of the Ickes Mountains (Figures $8 \mathrm{e}-8 \mathrm{~g}$ ). The granite intrudes folded and metamorphosed Lower Cretaceous volcanic rocks. The mean direction ( $D=340.7, I=-80.9, a_{95}=1.2^{\circ}$ ) (Table 1) is similar to the in situ mean direction from the Ickes Mountains syenite.

Cape Burks gabbro. Sixty-one oriented cores were collected from nine sites in a layered gabbroic complex at Cape Burks, on the coast approximately $25 \mathrm{~km}$ north of McDonald Heights (Figures $8 \mathrm{~h}-\mathbf{8 j}$ ). The samples were quite strongly magnetized, with NRMs ranging from 2 to $144 \mathrm{~A} / \mathrm{m}$, and yield very stable $\mathrm{ChRMs}$. Sun compass readings were taken for each sample at eight of the sites. Moderate to large deviations were seen in the magnetic compass readings so the Sun compass core azimuths were used for all samples. The results from one very strongly magnetized site had to be discarded because no Sun compass readings were taken due to sampling in shadow. The layering (sites 1 to $6:$ strike/dip $=340^{\circ} / 60^{\circ} \mathrm{E}$, sites 7 to
9: strike $/$ dip $=240^{\circ} / 35^{\circ} \mathrm{W}$ ) defines a plunging synform; the paleomagnetic directions from the two limbs are in reasonably good agreement before correcting for this apparent structure and diverge as a result of returning the limbs to the horizontal. Given the very strong magnetization and high stability in this gabbro it would seem that the magnetization is not likely a recent overprint. Therefore the synform may be the original layering attitude due to cooling on the walls of the magma chamber or an early collapse feature due to withdrawal of magma from an underlying magma chamber before cooling through the Curie temperature $\left(-580^{\circ} \mathrm{C}\right)$. The in situ mean direction is $D=171.7, I=-71.5, a_{95}=6.4^{\circ}$, for $N=8$ site means. The present result is similar to, but groups better than, a mean direction calculated from the Cape Burks results of Grindley and Oliver [1983] $\left(D=161.5, I=-79.8, a_{95}=18^{\circ}, N=3\right.$ sites $)$.

\section{Mean 100 Ma Paleomagnetic Pole Position for Marie Byrd Land}

The paleomagnetic results presented here are expected to represent circa $100 \mathrm{Ma}$ magnetizations because of (1) the high stability of the characteristic magnetization to both alternating field and thermal treatment in most samples; (2) the concordance of K-Ar [Spörli and Craddock, 1981; Grindley and Oliver, 1983] and ${ }^{40} \mathrm{Ar} /{ }^{39} \mathrm{Ar}$ [Palais et al., 1993] ages to Rb-Sr [R. J. Pankhurst, personal communication, 1993] and zircon U-Pb [Palais et al., 1993; D. G. Palais and S.B. Mukasa, personal communication, 1993] ages, implying a short emplacement history at about $100 \mathrm{Ma}$ and no younger thermal

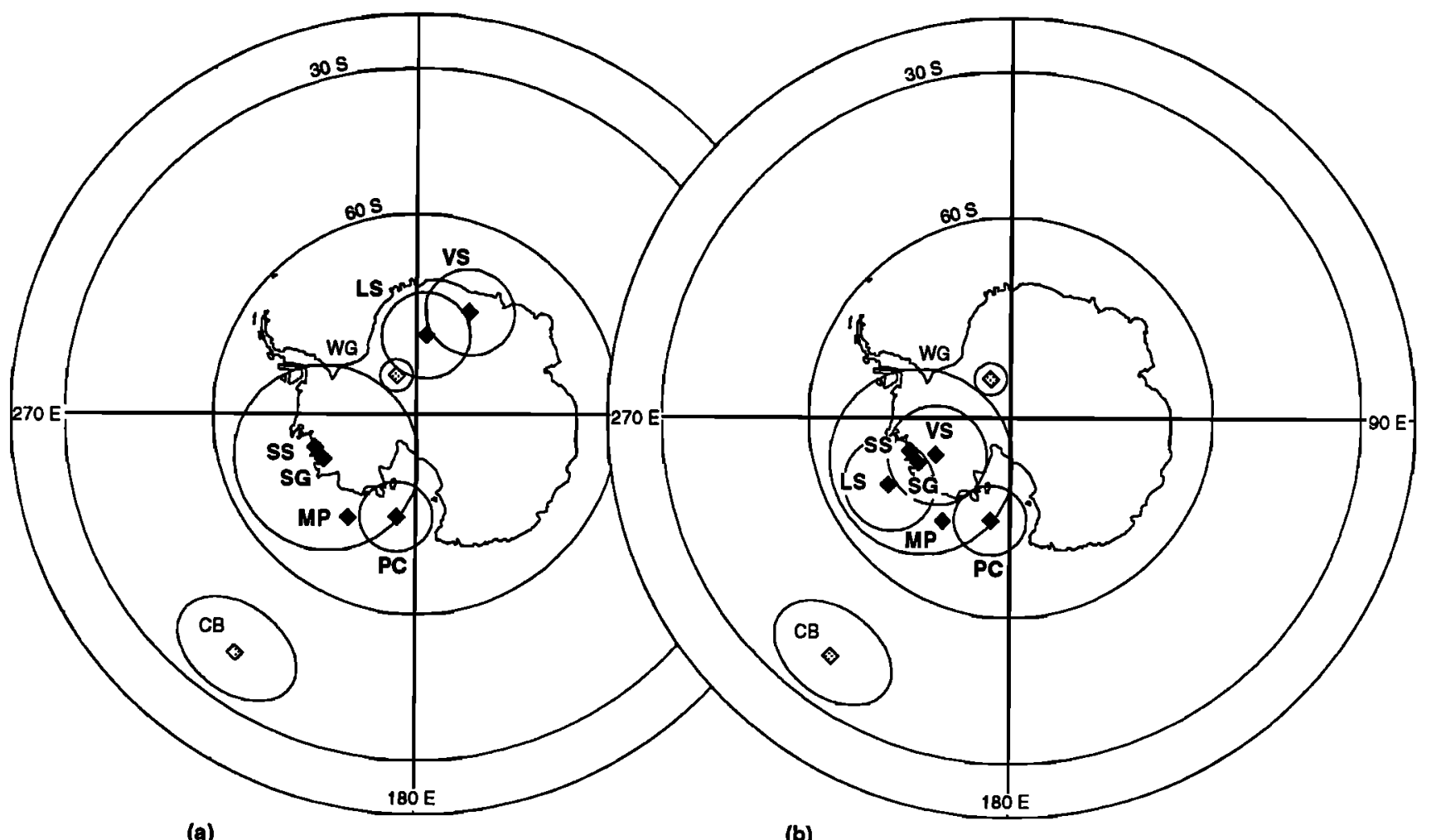

(a)

(b)

Figure 9. Circa $100 \mathrm{Ma}$ mean poles from Mount Sinha gabbro (SG), Sinha west nunatak syenite (SS), Peden Cliffs syenite (PC), Ickes Mountains syenites at Mount Vance and Mount Langway (VS and LS), Mount Petras (MP), Wilkins Nunatak granite (WG), and Cape Burks gabbro (CB) plotted with $A_{95}$ circles of confidence. (a) Before and (b) after tilt correction of Mount Vance and Langway syenites. This and following figures are orthographic projections. 
events; and (3) the uniform normal polarity consistent with magnetization acquisition and emplacement ages during the Cretaceous Normal Superchron (118 to $84 \mathrm{Ma}$ ) [Kent and Gradstein, 1986].

Mean paleomagnetic poles were calculated for each of the eight circa $100 \mathrm{Ma}$ locations by averaging the site mean virtual geomagnetic poles (VGP). A cluster of poles falls near the coast of MBL including poles from Peden Cliffs (PC), Mount Sinha syenite (SS), Sinha gabbro (SG), and Mount Petras (MP) (Figure 9a). The poles from Cape Burks gabbro (CB), Wilkins Nunatak granite (WG), and the in situ poles from the syenite at Mount Vance (VS) and Mount Langway (LS), however, fall some $30^{\circ}$ to either side of the cluster.

This spread of circa 100 Ma poles demands some explanation. Since the sampled units are all plutonic and therefore cooled slowly, the pattern is unlikely to represent paleosecular variation of the Earth's magnetic field. Also, the angular distance $\left(-65^{\circ}\right)$ between the Cape Burks and Mount Vance syenite in situ poles is much too great to be accounted for by apparent polar wander given the very similar ages of the rock units. Therefore given that New Zealand/Campbell Plateau rifted from this margin shortly before $85 \mathrm{Ma}$ [Mayes et al., 1990], a structural explanation appears likely.

Structural control is difficult to achieve in the Ruppert/Hobbs Coast area, which is characterized by isolated igneous outcrops separated by expanses of snow and ice. However, in the Ickes Mountains the syenite intrudes Lower Cretaceous bedded volcanics which outcrop at Mount Vance/Mount LeMasurier. Applying a tilt correction to the
Ickes Mountains syenite results using the average bedding attitude in the overlying volcanics (strike/dip $=270^{\circ} / 15^{\circ} \mathrm{N}$ ) (assuming the volcanics were flat-lying when the syenites acquired their magnetization) yields tilt-corrected mean poles for Mount Vance (VS) and Mount Langway (LS) that fall in the cluster with the McDonald Heights and Mount Petras results (Figure 9b). This agreement gives us confidence that the assumption of originally horizontal volcanic bedding is reasonable in this case. The consistent paleomagnetic directions observed across the relatively large area of McDonald Heights (Peden Cliffs, Mount Sinha, Sinha west Nunatak) implies no discernible differential block tilting within this area. The consistency of the mean pole from Mount Petras with the tiltcorrected Ickes Mountains results and the McDonald Heights results implies no relative tilts over an area of approximately $300 \mathrm{~km}$ parallel to the coast and $150 \mathrm{~km}$ inland, other than that observed in the Ickes Mountains. The tilt test, performed by combining the location mean poles from Mount Vance, Mount Langway, Peden Cliffs, Sinha gabbro, Sinha syenite, and Mount Petras before and after correcting for tilt at Vance and Langway, is statistically significant at the $95 \%$ (as well as 99\%) confidence level.

The similarity of the mean pole from Wilkins Nunatak to the mean poles from Mount Vance and Langway implies tilting of Wilkins nunatak in the same sense as the Ickes Mountains, and the close proximity of Wilkins Nunatak (15 $\mathbf{k m}$ to the south) to the demonstrably tilted Mount Vance and Mount Langway makes this a reasonable assumption. The position of the mean pole from Cape Burks, on the coast approx-

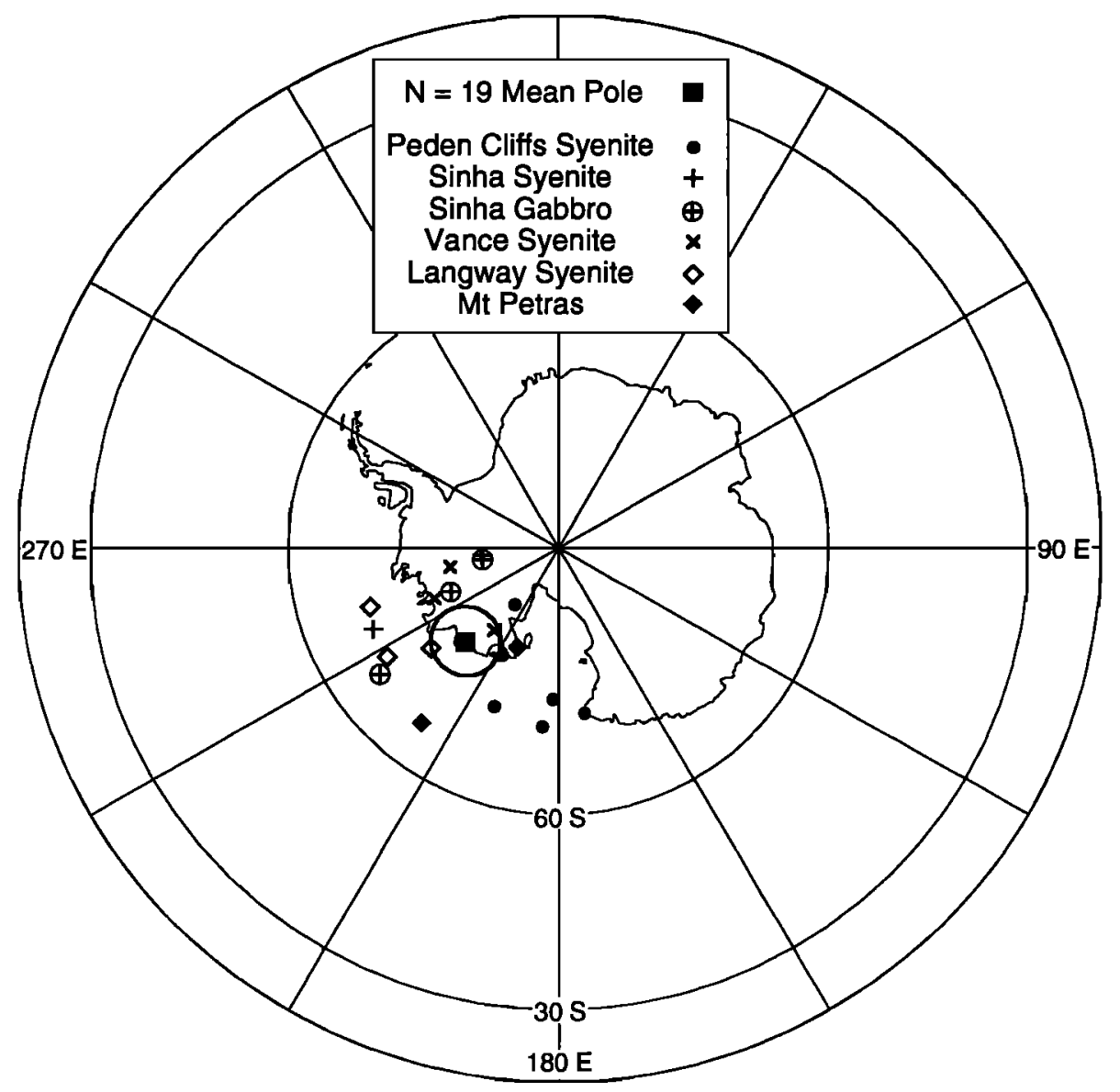

Figure 10. The $100 \mathrm{Ma}$ mean pole for Marie Byrd Land with $A_{95}$ circle of confidence, plotted with $N=19$ site means. 
imately $25 \mathrm{~km}$ to the north of McDonald Heights, implies $10^{\circ}$ to $15^{\circ}$ of tilting in the opposite sense as that in the Ickes Mountains, but again, about an east-west strike.

Given the consistency of the majority of the poles (PC, SS, SG, MP, VS tc, LS tc) over a large area of MBL, with a positive tilt test, we believe that these results should give a good estimate of the 100-Ma pole position for MBL. A circa $100 \mathrm{Ma}$ mean south paleomagnetic pole for MBL was calculated by combining the 19 site mean poles from McDonald Heights (Peden Cliffs syenite, Sinha syenite, Sinha west gabbro), Mount Petras, and the tilt corrected Ickes Mountains syenites (Mount Vance syenite, Mount Langway syenite) (Figure 10 and Table 1). The Cape Burks and Wilkins Nunatak results are not included because their deviation from the main group of VGPs is inferred to be the result of tilting but there are no paleohorizontal markers with which to make tilt corrections for these. It should be noted, however, that inclusion of both the Cape Burks and Wilkins Nunatak VGPs would not significantly alter the mean pole since these results fall on either side of the mean of the other 19 sites, and would carry approximately equal weight (eight sites versus six sites, respectively).

The circa $100 \mathrm{Ma}$ pole for MBL determined in the present study, $224.1^{\circ} \mathrm{E} / 75.7^{\circ} \mathrm{S}, A_{95}=3.8^{\circ}$, is significantly different from the MBL pole of Grindley and Oliver [1983] at $242^{\circ} \mathrm{E} /$ $65^{\circ} \mathrm{S}, A_{95}=8.8^{\circ}$ (Table 2, GO MBL 100 in Figure 11). The angular separation is $12.2^{\circ}$. Their mean pole was based on results from volcanic flows from Mount Petras, as well as a variety of dikes over much of the same area as the present study. They cited K-Ar ages from flows from the Mount Petras area and individual dikes from half of their remaining sampling locations ranging from approximately 90 to $110 \mathrm{Ma}$. Tilting of coastal fault blocks has been identified in the present study in the Ickes Mountains area and inferred for Cape Burks. Tilting presumably also affected the dikes sampled in the Ickes Mountains and at Cape Burks by Grindley and Oliver, even though they made no tilt corrections. The present Mount Petras results are consistent with the other circa $100 \mathrm{Ma}$ results that make up the new 100 Ma mean pole for MBL but there is a significant discrepancy between these results and the Mount Petras results of Grindley and Oliver [1983]. The rea- son for the difference is somewhat puzzling. The intrusive rocks sampled at Mount Petras in the present study yield a crystallization age, by the Rb-Sr method, of about $100 \mathrm{Ma}$, and bear an alkaline geochemistry similar to the alkaline igneous rocks on the Ruppert/Hobbs Coast (S. D. Weaver, personal communication, 1993). The "low-dipping...viscous rhyodacite flows" from Mount Petras studied by Grindley and Oliver [1983, p. 573] gave discordant K-Ar ages ranging from 81 to $104 \mathrm{Ma}$, but these may be minimum ages not reflecting the emplacement and magnetization age. They proposed calcalkaline geochemical affinities for these rocks which would suggest a relationship to Lower Cretaceous or older rock suites and not the circa $100 \mathrm{Ma}$ mid-Cretaceous alkaline suite. We note that the exclusion of our Mount Petras results would hardly affect our mean pole position, while the removal of Grindley and Oliver's Mount Petras results would make their mean pole not significantly different from our mean. The Cape Burks, Ickes Mountains, and Mount Petras site means of Grindley and Oliver [1983] accounted for 10 of the 26 site means that went into their overall mean pole. On the basis of the good age control for our sampled units, positive tilt test, and good agreement across a large area of MBL, we believe that our results represent an improved estimate of the circa 100 Ma paleomagnetic pole position for MBL located at $224.1^{\circ} \mathrm{E} /$ $75.7^{\circ} \mathrm{S}, A_{95}=3.8^{\circ}$.

\section{Testing the Integrity of Mid-Cretaceous West Antarctica}

Marie Byrd Land's immediate West Antarctic neighbors in the mid-Cretaceous included Thurston Island (TI) to the east and New Zealand/Campbell Plateau to the north. The boundary between MBL and the TI block is a deep glacially eroded trough in Pine Island Bay, which may also be related to the Udintsev Fracture Zone [Sandwell and McAdoo, 1988; SPRITE Group and Boyer, 1992; Lawver et al., 1993]. South New Zealand (SNZ) (including the Campbell Plateau and Chatham Rise) is separated from MBL by crust generated during Late Cretaceous to Recent seafloor spreading on the Pacific/Antarctic ridge. What follows is an evaluation of the new circa 100 Ma pole for MBL with respect to existing pale-

Table 2. West Antarctic Paleomagnetic Poles

\begin{tabular}{|c|c|c|c|c|c|c|}
\hline Block & Age & $N$ & $A_{95}$ & Plon ${ }^{\circ} \mathrm{E}$ & Plat ${ }^{\circ} \mathrm{N}$ & Source \\
\hline MBL & 100 & 19 & 3.8 & 224.1 & -75.7 & this study \\
\hline MBL & 100 & 26 & 8.8 & 242 & -65 & Grindley and Oliver [1983] \\
\hline TI & 110 & 7 & 7.6 & 210 & -73 & Grunow et al. $[1991]$ \\
\hline AP & 107 & 13 & 6.9 & 199 & -74 & Grunow $[1993]$ \\
\hline $\mathbf{A P}$ & 106 & 16 & 10.3 & 208.5 & -74.8 & $\begin{array}{l}\text { recalculated in this study from data of Kellogg and Rowley } \\
\text { [1989] and Kellogg [1980] }\end{array}$ \\
\hline AP & $106 \mathrm{M}$ & 29 & 6.2 & 203.8 & -74.3 & $\begin{array}{l}\text { calculated in this study from site means of Kellogg [1980], } \\
\text { Kellogg and Rowley [1989], and Grunow [1993] }\end{array}$ \\
\hline AP & 104 & 7 & 12.3 & 132 & -77 & Watts et al. [1984] \\
\hline AP & 102 & 18 & 11.5 & 229 & -87 & Kellogg and Reynolds [1978] \\
\hline AP & 98 & 5 & 8.8 & 117 & -86 & Valencio et al. [1979] \\
\hline $\mathbf{N}$ & 94 & 46 & 7.0 & 208 & -75 & Oliver et al. [1979] (174/-52 in NZ coordinates) \\
\hline
\end{tabular}

Crustal Blocks: MBL, Marie Byrd Land; TI, Thurston Island; AP, Antarctic Peninsula; NZ, New Zealand (reconstructed back to Marie Byrd Land after Mayes et al. [1990]). Age in mega annum; $N$, number of sites used to calculate mean; $A_{95}$, radius of the $95 \%$ cone of confidence about the mean pole; Plon and Plat are mean paleomagnetic pole east longitude and north latitude (negative is south latitude). 


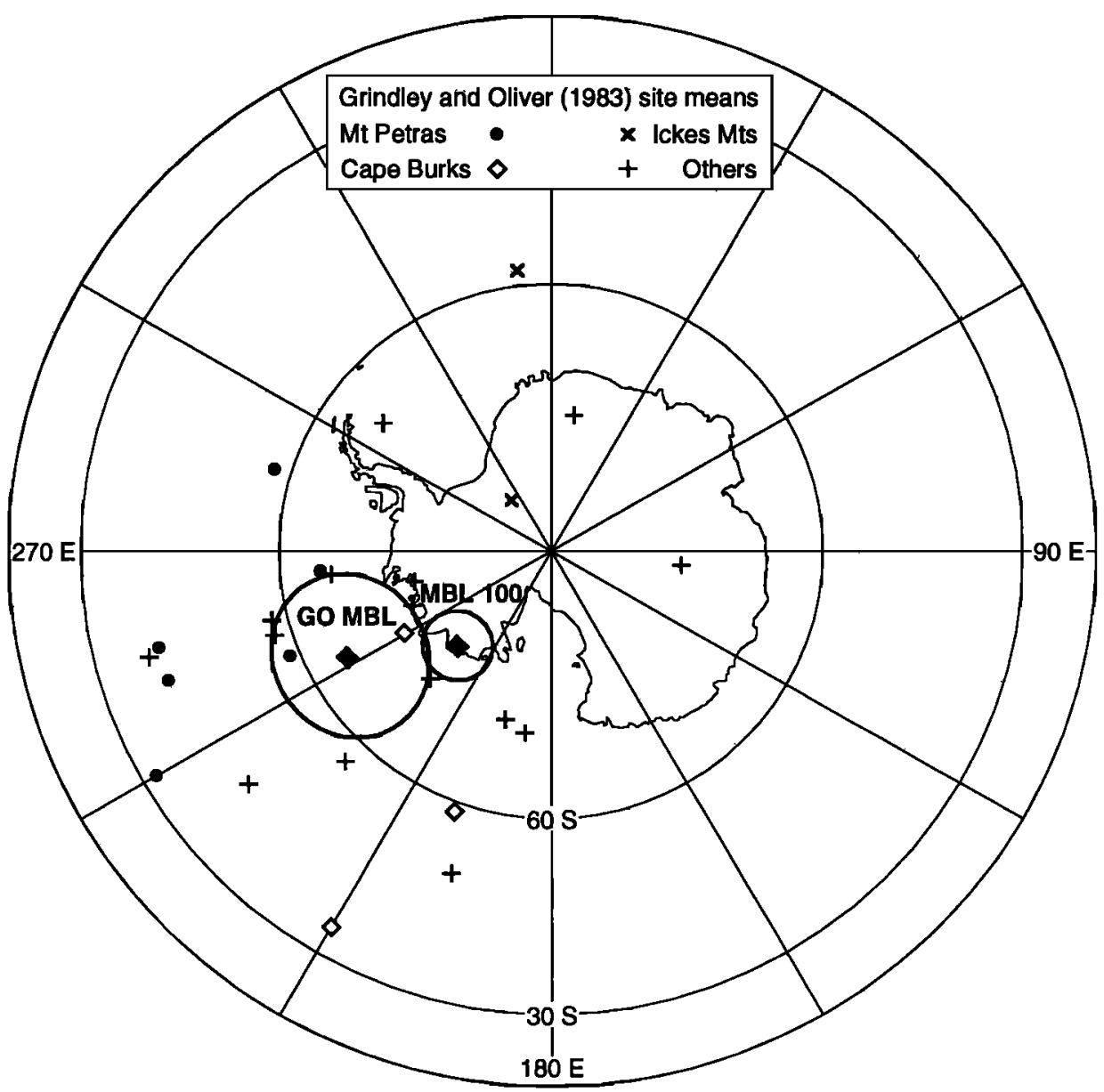

Figure 11. Comparison of the present result (MBL 100) with the previous result of Grindley and Oliver [1983] (GO MBL). Both mean poles plotted with $A_{95}$ circles of confidence. Additional poles are Grindley and Oliver's site means.

omagnetic data of similar age from TI and South New Zealand as well as the remainder of West Antarctica in order to evaluate the tectonic integrity of West Antarctica since the midCretaceous (Figure 12).

The present result (MBL 100 in Figure 12) is within $5^{\circ}$ and is not significantly different from the circa $110 \mathrm{Ma}$ pole from Thurston Island (TI 110 in Figure 12 and Table 2) of Grunow et al. [1991]. Grunow et al. [1991] noted that the MBL pole of Grindley and Oliver [1983] required relative motion between MBL and TI since about $100 \mathrm{Ma}$. However, our results show that MBL and TI have not experienced any paleomagnetically resolvable relative motion since about $100 \mathrm{Ma}$.

Oliver et al. [1979] reported a paleomagnetic pole from volcanic flows southeast of the Alpine Fault on South Island, New Zealand with K-Ar ages ranging from 92 to $98 \mathrm{Ma}$. Barley et al. [1988] reported an $\mathrm{Rb}-\mathrm{Sr}$ age of $89 \mathrm{Ma}$ from these rocks. This pole (NZ 94 in Figure 12 and Table 2), reconstructed to MBL using the rotation parameters of Mayes et al. [1990], is not significantly different from MBL 100 and TI 110 and lends support for a mid-Cretaceous pole position for MBL and TI, located adjacent to the coast of MBL.

For the remainder of West Antarctica, there are no post Middle Jurassic paleomagnetic results from EWM. However, several rather scattered mid-Cretaceous poles have been published from various AP locations.
From the southern AP, Kellogg [1980] reported paleomagnetic results from plutonic rocks from the Orville Coast region (Figure 1), with Rb-Sr ages ranging from 103 to $109 \mathrm{Ma}$. The mean pole $\left(195^{\circ} \mathrm{E} / 71^{\circ} \mathrm{S}\right)$ is in good agreement with MBL 100 , TI 110, and NZ 94. Kellogg and Rowley [1989] added three more site means and new $\mathrm{Rb}-\mathrm{Sr}$ and $\mathrm{K}$-Ar ages, ranging from 100 to $113 \mathrm{Ma}$. Combining all of the site means of Kellogg [1980] and Kellogg and Rowley [1989] gives a mean paleomagnetic pole for the southern $\mathrm{AP}$ at $208.5^{\circ} \mathrm{E} / 74.8^{\circ} \mathrm{S}, A_{95}=$ $10.3^{\circ}$ (AP 106 in Figure 12 and Table 2), which groups very well with, and is not significantly different from, MBL 100, TI 110 and NZ 94. Kellogg and Rowley [1989] had separated these results into two groups based on comparison of the declinations only, suggesting that one group was offset from the other as a result of oroclinal rotation of the southern AP. However, the nearly $25^{\circ}$ paleolatitudinal difference implied by their two group means can not be reconciled by simple vertical axis rotation. Bearing in mind that at high latitudes, $1^{\circ}$ of tilt equals nearly $2^{\circ}$ of pole shift, it seems much more likely that small tilts, comparable to those identified on the Ruppert/Hobbs Coast, contribute to the differences observed between the two groups. The combined mean pole calculated above may therefore provide a more valid estimate for the southern AP than either of the two group mean poles, since it may more completely average out the effects of possible tilts. 


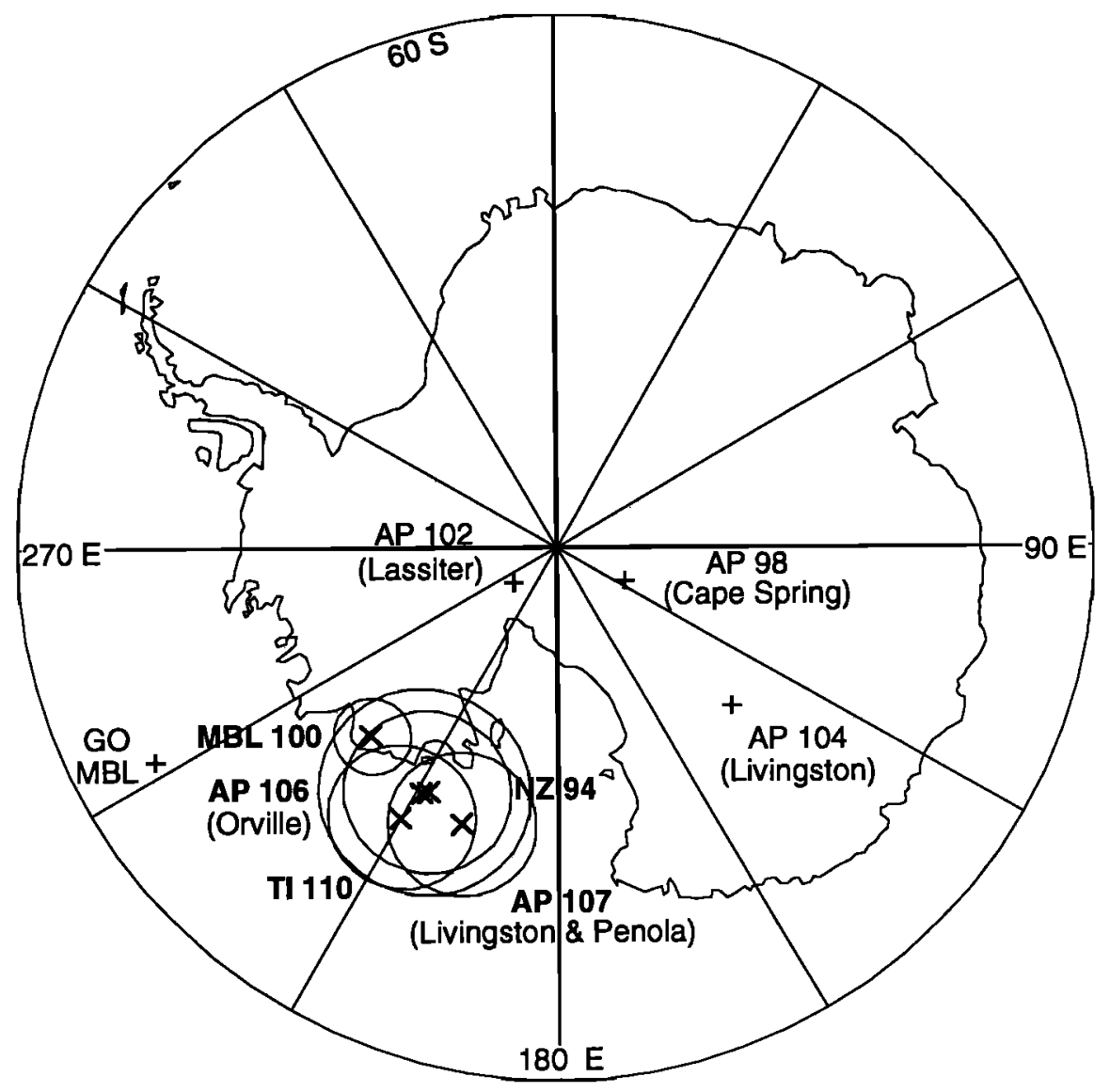

Figure 12. Marie Byrd Land and other West Antarctic circa 100 Ma poles: MBL 100 , the present result; GO MBL, previous result for MBL of Grindley and Oliver [1983]; TI 110 [Grunow et al., 1991]; AP 106 from the Orville Coast of the southern Antarctic Peninsula [Kellogg and Rowley, 1989] recalculated in this paper; AP 102 from the Lassiter Coast of the south-central Antarctic Peninsula [Kellogg and Reynolds, 1978]; AP 104 from Livingston Island, northern Antarctic Peninsula [Watts et al., 1984]; AP 107 from the northern Antarctic Peninsula [Grunow, 1993]; AP 98 from Cape Spring of the northern Antarctic Peninsula [Valencio et al., 1979]; NZ 94 from south New Zealand [Oliver et al., 1979] rotated back to Marie Byrd Land using the pole of rotation of Mayes et al. [1990]; selected poles shown with $A_{63}$ circles of confidence.

A recent study of mid-Cretaceous intrusive and extrusive rocks from Livingston Island and Penola Strait of the northern AP [Grunow, 1993] (Figure 1) yields a circa 107 Ma pole $\left(199^{\circ} \mathrm{E} / 74^{\circ} \mathrm{S}, A_{95}=6.9^{\circ}\right.$ ) (AP 107, Figure 12, Table 2) which agrees well with MBL 100, TI 110, AP 106, and NZ 94. As implied by Grunow [1993], the AP 107 result supersedes the previous result of Watts et al. [1984] (AP 104) from Livingston Island because 8 of 13 site means are from units that constituted (yet give different directions than) 4 of 7 site means of Watts et al. [1984].

There are two earlier results for circa 100 Ma rocks from AP, mostly from dikes, from the Lassiter Coast (Figure 1) of southcentral AP [Kellogg and Reynolds, 1978] (AP 102 in Figure 12 and Table 2) and Cape Spring (Figure 1) of northern AP [Valencio et al., 1979] (AP 98). Both results show uniform normal polarity and mean poles coincident with the dipole field (geographic pole), although the partial demagnetization procedures used should have been adequate to remove recently acquired viscous components. Watts et al. [1984] and Grunow [1993] suggested apparent polar wander as the cause for the difference between AP 107/AP 106 and AP 102/AP 98, but the angular distance $\left(14^{\circ}\right)$ seems to be rather large to be accounted for solely by apparent polar wander during this short time interval (about 4 to 9 m.y.). Also, the AP 102 and AP 98 poles are not consistent with MBL 100 , which would imply a complicated history of relative motions between AP and MBL contrary to the more consistent picture evidenced by the more recently published results (AP 107 and AP 106).

It is presently unclear whether the differences among the circa 100 to $110 \mathrm{Ma}$ paleomagnetic poles from AP discussed above are due to oroclinal rotation, localized rotations and/or tilts, significant differences in the magnetization ages of the units sampled (greater than those apparent from the cited radiometric ages), incomplete removal of overprints, or other causes. On the assumption that the two most recent studies [Kellogg and Rowley, 1989; Grunow, 1993] incorporate the best data, we calculate a circa $106 \mathrm{Ma}$ mean pole for AP by combining the site means from Grunow [1993] and Kellogg and Rowley [1989] (which includes site means from Kellogg [1980]). The mean pole is $203.8^{\circ} \mathrm{E} / 74.3^{\circ} \mathrm{S}, A_{95}=6.2^{\circ}$ for $N=$ 29 sites (AP $106 \mathrm{M}$ ), which fits very well with MBL 100, TI 110, and NZ 94.

It may be concluded from the correspondence of MBL 100 with TI 110 that the two blocks have not experienced any sig- 
nificant motion with respect to one another (or no more than that allowed by the paleomagnetic error) since about $100 \mathrm{Ma}$. Based on the assumptions above regarding the AP poles, it may also be concluded from the correspondence of AP $106 \mathrm{M}$ with MBL 100 and TI 110 that AP has not experienced any significant relative motion with respect to $\mathrm{MBL}$ and $\mathrm{TI}$ since about $100 \mathrm{Ma}$.

The agreement of the circa $175 \mathrm{Ma}$ poles from AP [Longshaw and Griffiths, 1983] and EWM [Grunow et al., 1987a] was cited as evidence that AP and EWM may have moved as a single entity since the Middle Jurassic [Grunow et al., 1987a]. More recently, Grunow [1993] proposed independent motions of AP, TI, and EWM during the Late Jurassic and Early Cretaceous, based on dissimilar paleomagnetic poles from AP and TI, even though there are no younger paleomagnetic results from EWM or even exposures of post-Middle Jurassic rocks with which to test either hypothesis. In either case, our analysis shows that most of the elements of West Antarctica (at least MBL, TI and AP) have not experienced paleomagnetically resolvable differential motion since about $100 \mathrm{Ma}$. The mid-Cretaceous mean paleomagnetic pole for $\mathrm{MBL}, \mathrm{TI}$, and AP is located at $212.2^{\circ} \mathrm{E} / 74.5^{\circ} \mathrm{S}, A_{95}=4.6^{\circ}$ for $N=3$ (MBL 100, AP 106M, TI 110) with an approximate mean age of $105 \mathrm{Ma}$.

\section{Comparison With East Antarctica: Synthetic Apparent Polar Wander Path for East Antarctica}

The mid-Cretaceous paleomagnetic poles from West Antarctica may be compared with an apparent polar wander path (APWP) for East Antarctica in order to test the midCretaceous to Recent integrity of Antarctica. However, the only reliable Mesozoic reference pole available for East Antarctica is the circa $175 \mathrm{Ma}$ pole based on many studies of the Ferrar Dolerites, Dufek Intrusion, and Kirkpatrick Basalts $\left(220.4^{\circ} \mathrm{E} / 52.7^{\circ} \mathrm{S}, A_{95}=4.4^{\circ}\right.$ ) [Kellogg, 1988]. There are no paleomagnetic results from rocks of Cretaceous age on the East Antarctic craton although several overprints of suspected Cretaceous age have been reported from Jurassic Ferrar Dolerite and Kirkpatrick Basalt as well as the CambroOrdovician Bowers Group in the area of the Rennick Graben in North Victoria Land [McIntosh et al., 1982; Delisle, 1983; Delisle and Fromm, 1984; Schmierer and Burmester, 1986; Delisle and Fromm, 1989]. Inclination-only data were obtained from the Kerguelen Plateau on the Antarctic plate for 70-90 Ma [Sakai and Keating, 1991] and 100-115 Ma [Inokuchi and Heider, 1992], but this type of data yields mean inclinations which tend to be biased toward shallower inclinations at high site paleolatitudes [McFadden and Reid, 1982], such as in these studies. Therefore, in order to compare the West Antarctic mid-Cretaceous paleomagnetic results with an East Antarctic reference, a synthetic APWP must be produced by transferring poles from other continents.

Irving and Irving [1982] compiled polar wander paths for the major continental blocks, excluding Antarctica. Besse and Courtillot [1991] constructed a synthetic apparent polar wander master path for the Atlantic-berdering continents by combining what they regarded as the most reliable data from North America, Eurasia, India, and Africa. Although Besse and Courtillot had the benefit of several newer poles and used more stringent selection criteria than did Irving and Irving, some additional paleomagnetic poles are now available for North America, and an updated age is available for a pole from India.
Also, Besse and Courtillot's plate reconstructions did not account for deformation within the African plate due to Cretaceous extension in the Benue Trough between about 136 and $84 \mathrm{Ma}$ [Burk and Dewey, 1974; Pindell and Dewey, 1982; Pindell et al., 1988]. For the purpose of producing a synthetic APWP it is important to consider the errors involved in the plate tectonic reconstructions used and to transfer data through independent plate circuits, if possible, in order to avoid a potentially systematic bias due to errors in a single reconstruction. In this study we construct a Cretaceous to Recent synthetic APWP for East Antarctica with an emphasis on the midCretaceous in order to facilitate a comparison of the West Antarctic mid-Cretaceous results with an East Antarctic reference. The new path utilizes some recently published poles and recent plate tectonic reconstructions, incorporates the Benue Trough opening into the reconstruction, and transfers poles through two independent plate circuits (Africa-Antarctica and Australia-Antarctica). Details of the pole selection and plate kinematic model are given in the Appendix.

The selected paleomagnetic reference poles, rotated into the East Antarctic reference frame (Table A1, Appendix), lie in a tight swath (Figure 13) which suggests that the individual poles are each reasonable estimates of the magnetic field and that there are no major problems with the reconstructions. The $95 \mathrm{Ma}$ pole from Australia groups well with $95 \mathrm{Ma}$ poles from Africa and the $100 \mathrm{Ma}$ pole from North America, and the $112 \mathrm{Ma}$ pole from Australia lies between the $112 \mathrm{Ma}$ pole from Africa and the $116 \mathrm{Ma}$ pole from India, supporting the validity of the reconstructions. Mean poles were calculated at $10 \mathrm{~m} . \mathrm{y}$. intervals from 125 to $75 \mathrm{Ma}$ using a 20-m.y.-wide sliding window. The mean poles (also listed in Table A2, Appendix) are labeled according to the mean age of the combined poles rather than the center of the window.

The synthetic APWP for East Antarctica is compared in Figure 14 with Besse and Courtillot's [1991] master path rotated from Africa into the East Antarctic reference frame using rotation poles interpolated from their plate kinematic model [Besse and Courtillot, 1988] (based on work by Segoufin [1980], Segoufin and Patriat [1980], Patriat [1983], and Patriat et al. [1985]) and using their chosen magnetic polarity timescale [Harland et al., 1982]. Their mean poles are also labeled according to mean age rather than window center. Even though the data sets and reconstruction models are somewhat different, the resultant paths are similar. The principal differences are (1) our Early Cretaceous poles (125 and $117 \mathrm{Ma}$ ) are more westerly than the Early Cretaceous poles (127 and 121 $\mathrm{Ma}$ ) of Besse and Courtillot, partly due to our compensation for extension in the Benue Trough in our plate kinematic model; (2) their 121, 112, and $98 \mathrm{Ma}$ mean poles approach the south pole more quickly than our 117, 102, and 93 Ma poles; and (3) their Late Cretaceous poles and Cenozoic poles remain nearer to the present geographic south pole than do ours.

The mid-Cretaceous mean poles from MBL, TI, and AP are plotted against the East Antarctic APWP in Figure 15. MBL $100, \mathrm{AP} 106 \mathrm{M}$, and TI 110 are all offset to the east of the East Antarctic APWP and are significantly different from it (MBL 100 and TI 110 are significantly different from both the 102 and 117 Ma East Antarctic mean poles; AP 106M is significantly different from the $102 \mathrm{Ma}$ East Antarctic pole but not significantly different from the $117 \mathrm{Ma}$ pole, though the latter test is marginal and inconclusive [McFadden and Lowes, 1981]). The mean pole for the Pacific-bordering blocks of West Antarctica (MBL, TI, AP), calculated from MBL 100, TI 


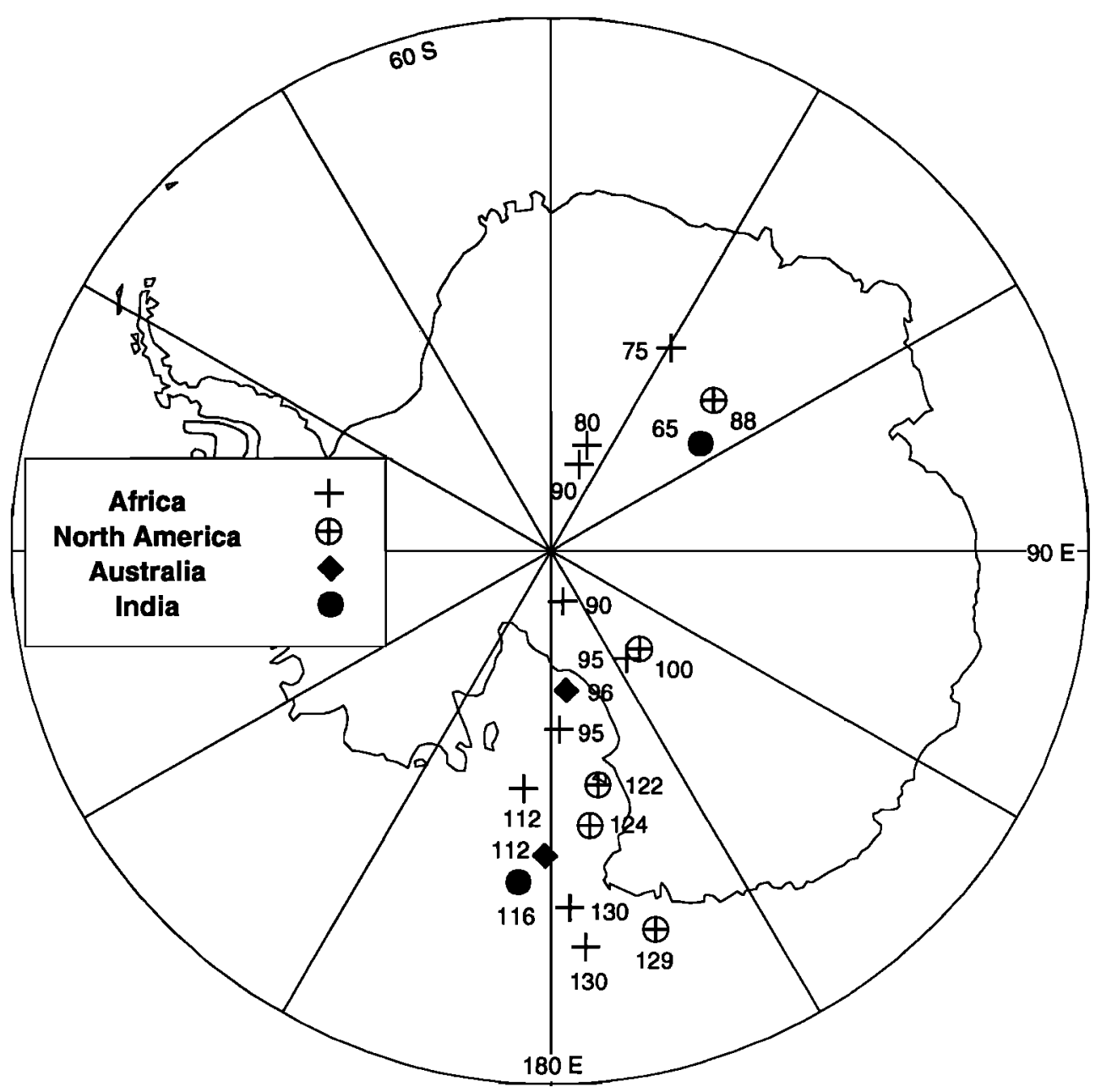

Figure 13. Cretaceous poles transferred from Africa, North America, India, and Australia into the East Antarctic reference frame. Poles are listed in Table A1.

110 , and $\mathrm{AP} 106 \mathrm{M}\left(212.2^{\circ} \mathrm{E} / 74.5^{\circ} \mathrm{S}, A_{95}=4.6^{\circ}\right)$, is significantly different from the East Antarctic APWP (compared to both the East Antarctic 102 and $117 \mathrm{Ma}$ poles). The angular distance separating the Pacific West Antarctic circa $105 \mathrm{Ma}$ mean pole and the $102 \mathrm{Ma}$ mean pole for East Antarctica is $10.2^{\circ} \pm 6.2^{\circ}\left(8.6 \pm 5.4^{\circ}\right.$ to East Antarctica $117 \mathrm{Ma}$ pole $)$.

Our preferred plate kinematic model used in constructing the APWP assumes a two plate configuration for Africa, with Early to mid-Cretaceous extension in the Benue Trough (see Appendix). As a check, we recalculated the APWP assuming a one plate Africa. The East and West Antarctic mean poles remain significantly different in this model as well.

The error assigned to the APWP is only based on the distribution of poles and does not include uncertainties in the rotation parameters for transferring poles to East Antarctica. Duncan and Richards [1991] noted that typical uncertainties for relative plate motion additions, as calculated by Molnar and Stock [1987], are in the 200 to $300 \mathrm{~km}$ range. Given the tightness of the swath of rotated poles (Figure 13), we believe that 200 to $300 \mathrm{~km}$ should represent a maximum reconstruction uncertainty (i.e., some of the reconstruction uncertainty is averaged out by combining independent plate circuits). The Pacific West Antarctic (MBL, TI, AP) mean pole is significantly different from the East Antarctic APWP even with the addition of a full $300 \mathrm{~km}$ of reconstruction related error; the angular separation from the East Antarctic $102 \mathrm{Ma}$ pole then becomes $10.2^{\circ} \pm 8.9^{\circ}\left(8.6^{\circ} \pm 8.1^{\circ}\right.$ to East Antarctica $117 \mathrm{Ma}$ pole).

The circa 98 and 112 Ma mean poles from the APWP of Besse and Courtillot [1991] rotated into an East Antarctic reference frame (Figure 14) are farther removed from the West Antarctic poles and support these observations. It can therefore be concluded that there has been a paleomagnetically resolvable movement of Pacific West Antarctica (MBL, TI and AP) with respect to East Antarctica since about $100 \mathrm{Ma}$.

\section{Tectonic Implications}

The paleomagnetic evidence for post-100 Ma relative motion between East Antarctica and Pacific West Antarctica is consistent with mounting geological evidence that the area between the Transantarctic Mountains (TAM) and the coastal areas of West Antarctica represents a Mesozoic-Cenozoic rift system. This area was termed the West Antarctic Rift System by LeMasurier [1978]. Fitzgerald [1992] concludes that the TAM are probably a rift-margin uplift. Stern and ten Brink [1989] modeled the TAM in terms of flexural uplift along the boundary between thermally old East Antarctic lithosphere and 


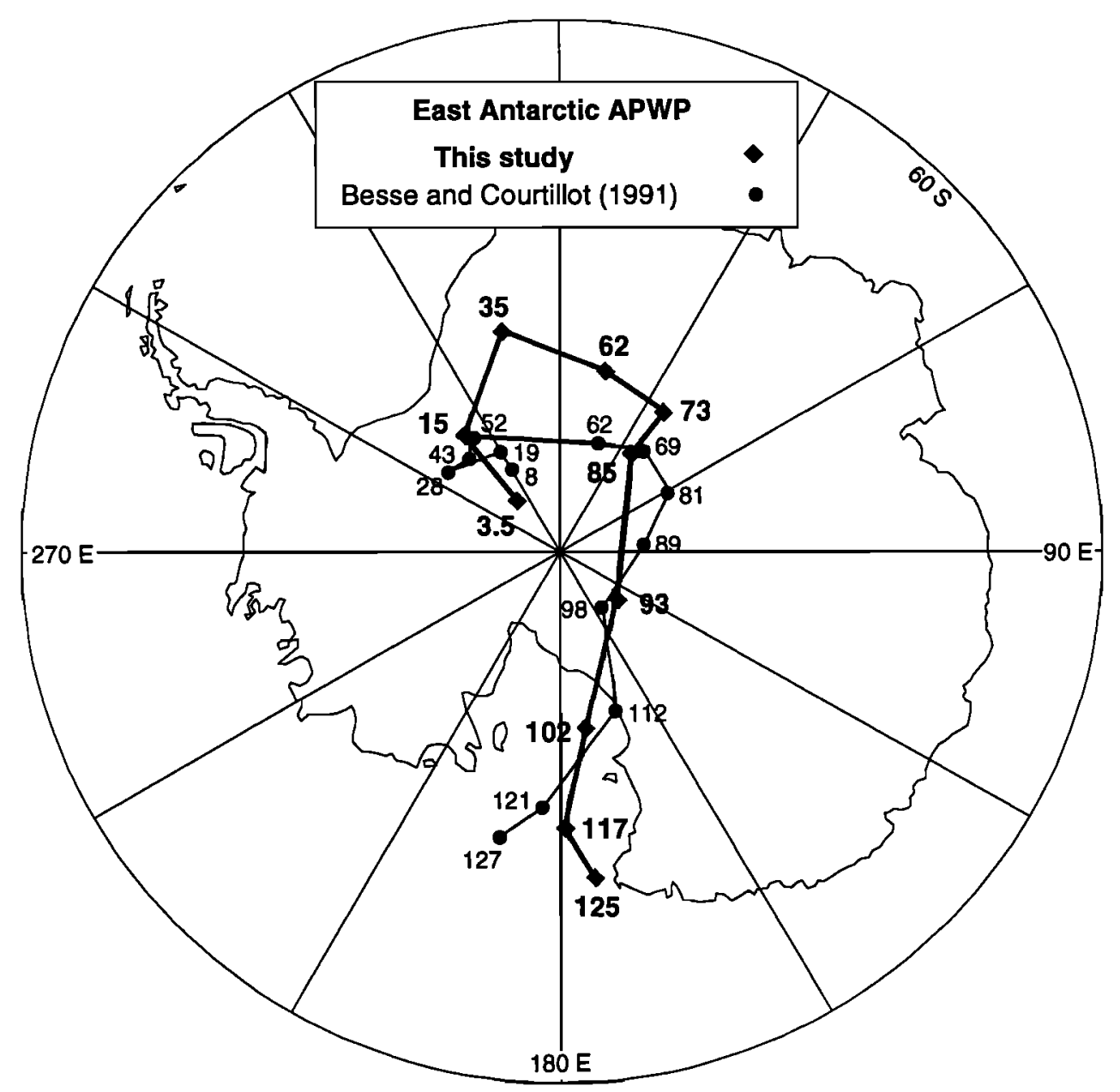

Flgure 14. Comparison of the newly constructed APWP for East Antarctica with the master APWP of Besse and Courtillot [1991] rotated into the East Antarctic reference frame.

thermally young West Antarctic lithosphere, but ten Brink et al. [1993] consider this inadequate and propose lateral heat flow from the rift to account for TAM uplift. North-south linear basins in the Ross Sea are parallel to the TAM and appear to continue beneath the Ross Ice Shelf. From west to east, the Victoria Land Basin, Central Trough, and Eastern Basin are separated by interbasin highs (Figure 1). Up to $14 \mathrm{~km}$ of sediments have been seismically imaged in the Victoria Land Basin [Cooper et al., 1987] and a maximum of $7 \mathrm{~km}$ of strata in the Central Trough and Eastern Basin [Davey et al., 1983]. The interbasin highs swing to a NNW-SSE trend southwards beneath the Ross ice shelf, following the trend of the TAM.

Fitzgerald [1992] and Wilson [1993] identify a component of dextral motion from the pattern of Cenozoic normal faulting in the TAM in addition to the dominant extensional component oriented perpendicular to the trend of the TAM. Storey [1991] suggests that the deep lozenge-shaped subglacial basins between MBL, TI, and EWM, the Bentley Subglacial Trench and the Byrd Subglacial Basin (Figure 1), may be pull apart basins formed at releasing bends of a dextral strike-slip fault system.

The oldest sediments thus far drilled in the Ross Sea are Lower Oligocene, 33-38 $\mathrm{Ma}$, from the CIROS-1 drill hole in McMurdo Sound [Barrett, 1987], though basement was not reached. Drilling at Deep Sea Drilling Project (DSDP) Site 270 in the south central Ross Sea bottomed in marble and calc-silicate gneiss basement rocks [Ford and Barrett, 1975] similar to calcareous metasedimentary rocks of the lower Paleozoic Skelton Group of southern Victoria Land [Blank et al., 1963] and calc-silicate gneiss and marble at Mount Murphy in eastern MBL [DiVenere et al., 1993]. The gneiss at Site 270 is overlain by $25 \mathrm{~m}$ of breccia capped by a subaereal paleosol [Ford and Barrett, 1975]. Unconformably overlying the paleosol is a mid-upper Oligocene to Recent sedimentary sequence, including $1 \mathrm{~m}$ of shallow water carbonaceous sandstone, $1 \mathrm{~m}$ of shallow marine glauconitic sandstone (K-Ar age of $26 \mathrm{Ma}$ ), and $384 \mathrm{~m}$ of glaciogenic sediments, which subsided from sea level to $500 \mathrm{~m}$ depth (current water depth is $630 \mathrm{~m}$ ) by the end of the early Miocene [Hayes and Frakes, et al., 1975]. The deepening was ascribed to either tectonic subsidence or isostatic compensation due to glacial loading of the continent [Hayes et al., 1975; Hayes and Frakes, 1975].

Cooper et al. [1991] summarized multichannel seismic reflection data of Hinz and Block [1984] and Cooper et al. [1987] in a generalized profile across the Ross Sea that shows fault bounded sedimentary basins in the Victoria Land basin and sediments draping faulted basement to the west in the remainder of the Ross Sea. Based on the profile (combined with the CIROS-1 and Site 270 data), faulting in the eastern twothirds of the Ross Sea ended before the mid-upper Oligocene 


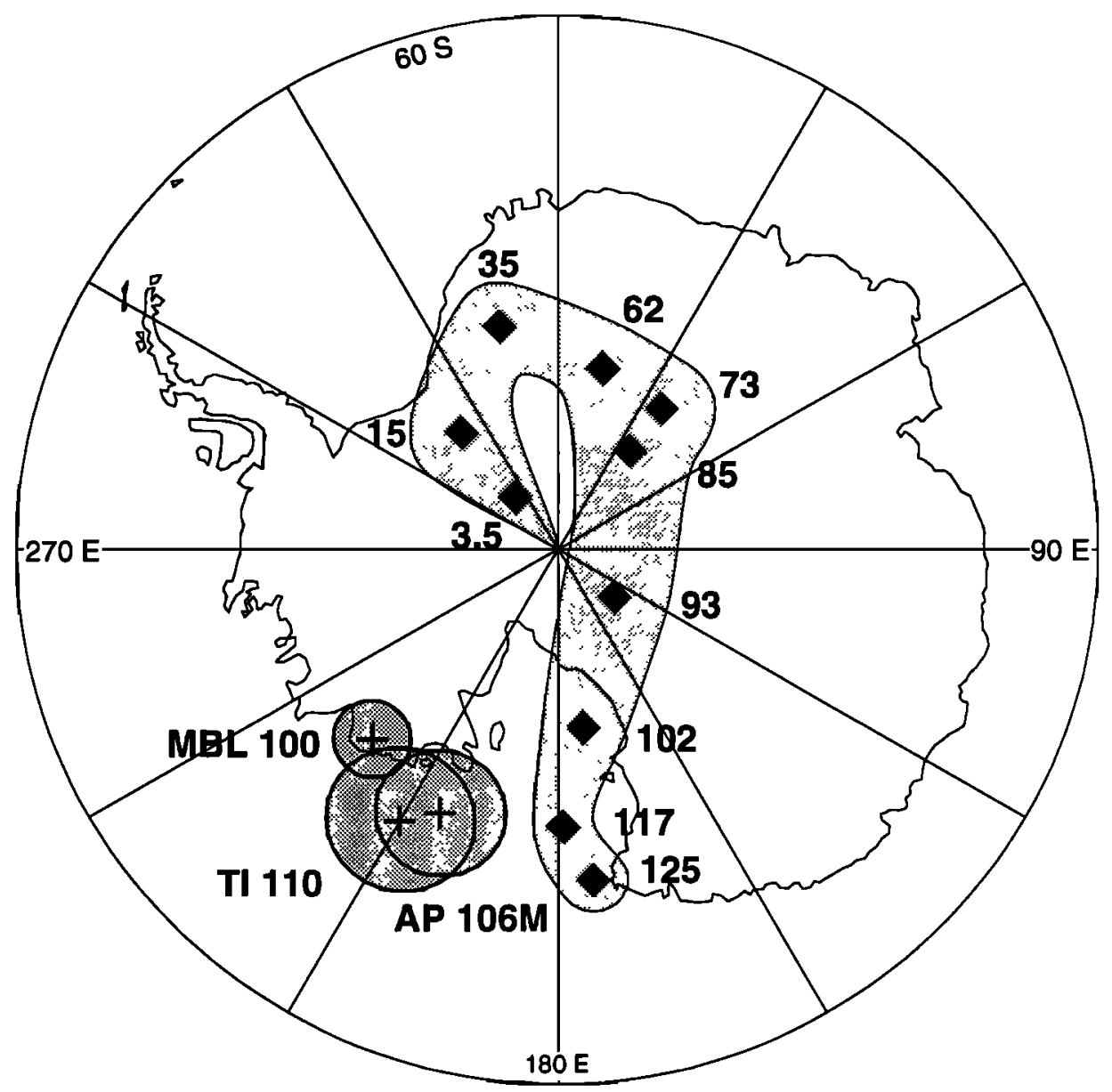

Figure 15. The 100 to $110 \mathrm{Ma}$ poles from MBL, TI, and the southern AP, with $A_{63}$ circles of confidence, plotted against the East Antarctic APWP with $A_{63}$ error envelope. The envelope for the APWP was constructed by drawing a smooth curve tangent to the $A_{63}$ circles of the mean poles. West Antarctic poles are listed in Table 2. East Antarctic poles are listed in Table A2.

unconformity seen at the bottom of Site 270 , but apparently continued to Recent times in the Victoria Land basin adjacent to the TAM (Figure 1).

Fitzgerald [1992] and Stump and Fitzgerald [1992] infer four phases of uplift in the TAM from apatite fission-track age profiles. The episodes are at approximately $110 \mathrm{Ma}$, which they associate with initial rifting of Australia, $80 \mathrm{Ma}$, which they associate with the separation of New Zealand and Australia from Antarctica, $55 \mathrm{Ma}$, the time of cessation of spreading in the Tasman Sea, and Plio-Pleistocene times, during which period there is a renewal in alkaline volcanism in the western Ross Sea and in MBL, possibly including subglacial volcanoes and high beat flow within the West Antarctic rift system [Blankenship et al., 1993]. However, Wilch et al. [1993] and ten Brink et al. [1993] present results that minimize any late Pliocene to Recent uplift.

Estimates of the amount of extension in the Ross Sea have been made by comparing the thickness of the crust on either side of the boundary between East and West Antarctica. Crustal thickness in the West Antarctic rift system is generally in the range $17-23 \mathrm{~km}$ with thicknesses of $27 \mathrm{~km}$ under Ross Sea basement gravity highs, whereas the thickness of the adjacent TAM rift shoulder is about $40 \mathrm{~km}$ [Behrendt and Cooper, 1991; Bentley, 1991; Cooper et al., 1991]. From this, Behrendt and Cooper [1991] inferred $350 \mathrm{~km}$ of extension in the Ross Sea, or about $50 \%$ of the nominal present-day width. However, the Phanerozoic crust of West Antarctic (excluding EWM) may not have been as thick as the Precambrian cratonic crust of East Antarctica. The average crustal thickness of coastal West Antarctica appears to be about $30 \mathrm{~km}$ [Bentley et al., 1960; Adams, 1972; Bentley, 1991], which would imply only about $275 \mathrm{~km}$ of extension. These crude estimates then suggest about $300 \mathrm{~km}$ (275 to 350 $\mathrm{km}$ ) of extension across the Ross Sea between Pacific West Antarctica and cratonic East Antarctica.

The Pacific West Antarctic circa 105 Ma mean pole is offset from the East Antarctic $102 \mathrm{Ma}$ pole by $10.2 \pm 6.2^{\circ}$ (or $\pm 8.9^{\circ}$ with the addition of the maximum reconstruction related error). Since the West Antarctic pole is located over the coast of MBL it implies a similar movement of MBL (plus TI and the southern AP) from East Antarctica. Translating the angular offset into kilometers by assuming a simple extension history about a distant euler pole, implies about $1130 \pm 690 \mathrm{~km}$ of relative motion between East and West Antarctica (1130 $\pm 990 \mathrm{~km}$ with the maximum reconstruction error). The range of paleomagnetically acceptable motions of Pacific West Antarctica with respect to East Antarctica is thus about 440 to $1820 \mathrm{~km}$ (140 to $2120 \mathrm{~km}$ with maximum reconstruction error). 


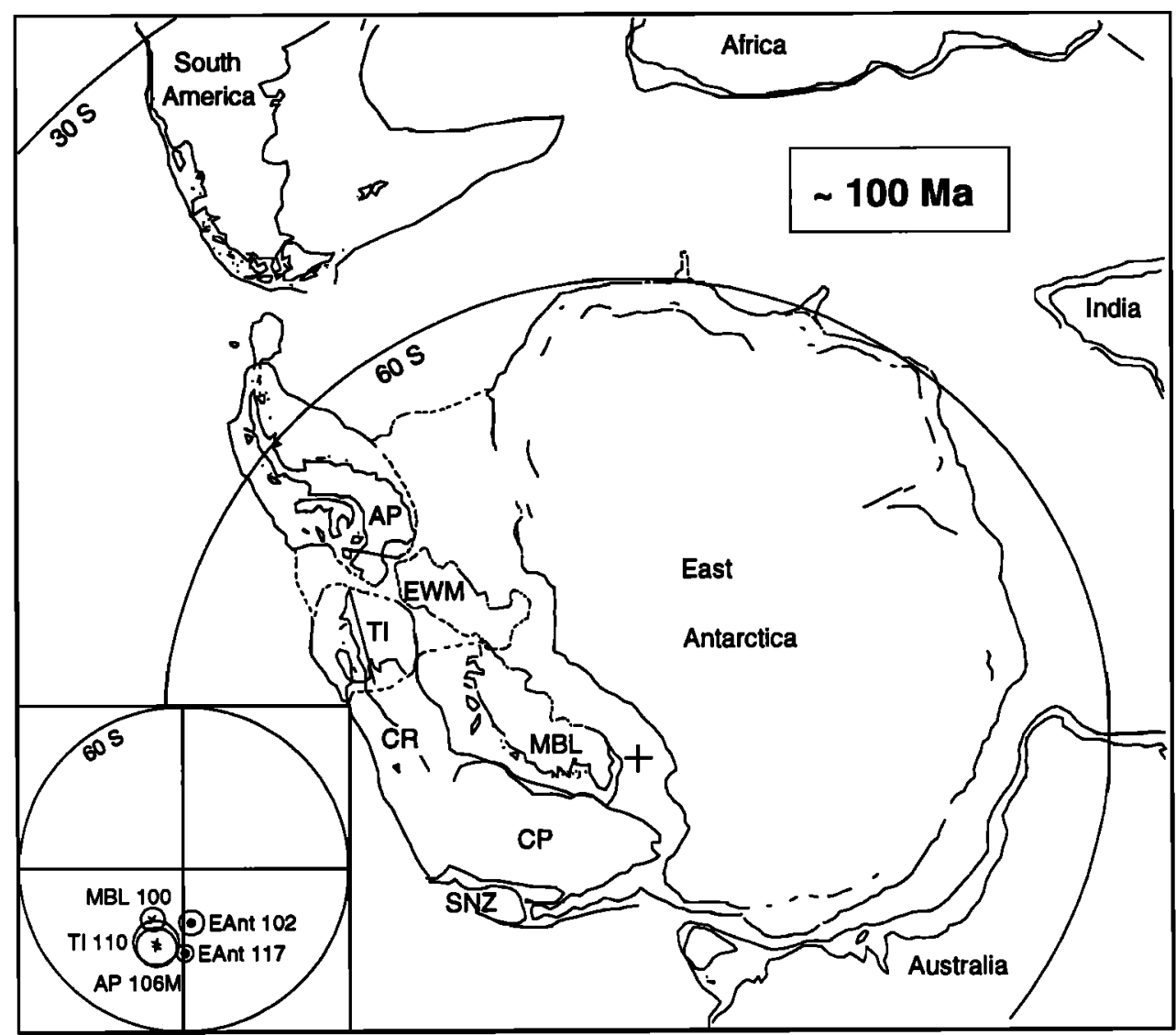

Figure 16. A circa $100 \mathrm{Ma}$ reconstruction with south pole centered on the East Antarctic $102 \mathrm{Ma}$ mean pole. South New Zealand (SNZ), including Campbell Plateau (CP) and Chatham Rise (CR), are restored to MBL. Inset shows West Antarctic poles (MBL 100, TI 110, and AP 106M) in their reconstructed positions with respect to the circa 117 and $102 \mathrm{Ma}$ East Antarctic mean poles (EAnt 117 and 102), all with $A_{63}$ circles of confidence.

The best paleomagnetic estimate $(1130 \mathrm{~km})$ for separation between East Antarctica and Pacific West Antarctica is close to the largest dimension across the Ross Sea (about $1030 \mathrm{~km}$ from Edward VII Peninsula of MBL to the Borchgrevink Coast of North Victoria Land, East Antarctica) (Figure 1) and is considerably larger than the nominal geological estimate of extension (about $300 \mathrm{~km}$ ) from crustal thickness arguments. We regard the paleomagnetic analysis to be reasonable and conservative because (1) our East Antarctic APWP yields a smaller offset with respect to the mid-Cretaceous Pacific West Antarctic paleomagnetic poles than the alternate APWP of Besse and Courtillot [1991], and (2) the new paleomagnetic pole for MBL, which is consistent with poles from TI and AP, greatly reduces the amount of extension that would be required in the Ross Sea compared to the previous MBL result of Grindley and Oliver [1983], which was inconsistent with the other West Antarctic results. The amount of extension expected from the comparison of crustal thicknesses may underestimate the true separation between East Antarctica and MBL because, for example, the crustal thicknesses may not be accurately known, there could be oceanic crust flooring the rift basins, and extension could have occurred over a larger area including intervening portions of MBL. In any case, the geological estimate is within the maximum error of the paleomagnetic estimate and the two estimates are therefore not incompatible. Both support relative motion between MBL (plus TI and AP) and East Antarctica of some hundreds of kilometers.
The timing of this extension is constrained by the paleomagnetic and geochronologic data to postdate $100 \mathrm{Mr}$. According to the geologic evidence, the largest portion likely occurred sometime prior to the mid-Late Oligocene after which time all extension appears to be confined to only the western third of the Ross Sea. The Ross Sea could have experienced a major episode of extension during Late Cretaceous rifting of the New Zealand continental block preceding its separation from Antarctica at about $85 \mathrm{Ma}$. If all significant East-West Antarctic motion ceased by the time of New Zealand separation it would imply, in conjunction with the paleomagnetic data, a separation rate equivalent to $7.5 \pm 6.5 \mathrm{~cm} / \mathrm{yr}$ between East Antarctica and Pacific West Antarctica over the interval 100 to $85 \mathrm{Ma}$. Alternatively, if East-West Antarctic relative motion continued into the Cenozoic, lower separation rates are implied. In that case MBL-East Antarctic relative motions would affect the plate circuit linking the Pacific and African hotspots [Molnar and Stock, 1987; Duncan and Richards, 1991].

We next consider the reconstruction of the 100 Ma position of the West Antarctic blocks with respect to East Antarctica. Given the lack of a circa 100 Ma pole for EWM, it is left in its present position with respect to East Antarctica. The simplest model is to rotate MBL, TI, and AP about a common rotation pole. However, it is difficult to reconcile the circa $100 \mathrm{Ma}$ paleomagnetic poles and the geologic constraints by a simple rigid rotation of Pacific West Antarctica back to East Antarctica due to problems of overlap of AP with EWM, and 
creation of gaps (implying later subduction) in the Weddell Sea and in the Drake Passage. We note that at face value (disregarding the circles of confidence about the paleomagnetic poles) $\mathrm{MBL} 100$ is offset the farthest from the East Antarctic APWP and AP 106M is offset the least. We therefore choose as a second possibility to allow some differential motion between the Pacific West Antarctic blocks within the errors of the West Antarctic paleomagnetic poles. A possible reconstruction is shown in Figure 16 in which South New Zealand and Campbell Plateau are restored back to MBL [after Mayes et al., 1990], MBL is restored to East Antarctica by approximately $50 \%$ closure of the Ross Embayment, TI is rotated moderately and AP only slightly counterclockwise. This model is at the limits of both the paleomagnetic error constraints as well as the geologic spatial constraints. The Pacific West Antarctic paleomagnetic poles are restored nearer to the East Antarctic APWP: TI 110 is reconciled with the East Antarctic APWP, AP 106M is at the limit of the paleomagnetic error, and MBL 100 may only be reconciled with the inclusion of reconstruction related error. At the same time, the model requires a large amount of extension (approaching 100\%) in the northern Ross Sea. However, the Campbell Plateau is shown with its present outline, though it is also likely to consist of extended continental crust (Bradshaw [1991] suggested about $30 \%$ extension). Accounting for Campbell Plateau extension would reduce the amount of extension required for the northern Ross Sea crust. This model implies a post $100 \mathrm{Ma}$ shear zone between MBL and TI, which Grunow et al. [1991] had previously suggested based on the comparison of TI 110 with the MBL result of Grindley and Oliver [1983].
There presently is no completely satisfying solution for the $100 \mathrm{Ma}$ reconstruction, but the new paleomagnetic constraints presented here suggests a larger amount of total extension between East and West Antarctica (MBL) than previously suspected from geological arguments.

\section{Appendix: Synthetic Apparent Polar Wander Path for East Antarctica}

The most comprehensive paleomagnetic data sets for the Cretaceous are from North America and Africa (Table A1). We also use paleopoles from India, as did Besse and Courtillot [1991], but unlike them we do not use the poles from Eurasia because: (1) their selected data set contains no mid-Cretaceous results, which are of greatest interest here, (2) the Early Cretaceous results from China and Korea require the assumption of no internal deformation of Eurasia since that time, even though this may not be specifically true considering the complex tectonics associated with the collision of India with Eurasia, and (3) use of the Eurasia poles requires a very long plate circuit with two additional relative motion pairs (Eurasia/Greenland and Greenland/North America) to transfer the poles to Antarctica. The African, Indian, and North American poles must ultimately all be transferred through the Africa-Antarctica plate circuit, and therefore their reconstruction associated errors are not entirely independent. The Australian poles then become an important check on the reconstructions. We rely largely on the pole selection criteria of other authors in recent reviews of Cretaceous results from Africa [Hargraves, 1989], North America [Globerman and

Table A1. Paleomagnetic Poles Transferred to East Antarctic Reference Frame

\begin{tabular}{|c|c|c|c|c|c|c|c|c|}
\hline \multirow[b]{2}{*}{ Pole } & \multirow[b]{2}{*}{ Age } & \multirow[b]{2}{*}{$A_{95}$} & \multicolumn{2}{|c|}{ Original } & \multicolumn{2}{|c|}{ Transferred } & \multirow[b]{2}{*}{ Continent } & \multirow[b]{2}{*}{ Source } \\
\hline & & & Plon & Plat & PLon & Plat & & \\
\hline Deccan Traps & 65 & 2.4 & 101.3 & -36.9 & 54.4 & -80.0 & India & 1 \\
\hline Madagascar dolerite and volcanics & 75 & 4.1 & 39.6 & -63.5 & 30.8 & -77.1 & Africa & 2 \\
\hline Fuerteventura lavas & 80 & $4.8 \dagger$ & 40.8 & -68.8 & 18.8 & -84.0 & Africa & 3 \\
\hline Niobrara Formation & 88 & 4 & 188.0 & 64.0 & 47.3 & -78.0 & North America & 4 \\
\hline Kimberlite pole 1 & 90 & 5.2 & 46.1 & -64.1 & 17.9 & -85.1 & Africa & 5 \\
\hline Madagascar volcanics & 90 & 4.9 & 60.0 & -69.1 & 166.0 & -87.2 & Africa & 2 \\
\hline Wadi Natash & 95 & 5.8 & 78.1 & -69.3 & 177.7 & -80.3 & Africa & 6 \\
\hline Wadi Natash* & 95 & 3.6 & 70.9 & -64.7 & 144.8 & -82.9 & Africa & 7 \\
\hline Mount Dromedary & 96 & 9.9 & 138.0 & -56.0 & 173.5 & -82.4 & Australia & 8 \\
\hline Magnet Cove & 100 & 4.6 & 197.3 & 72.6 & 137.9 & -82.9 & North America & 9 \\
\hline Lupata Lava & 112 & 4.0 & 79.0 & -61.8 & 186.7 & -77.0 & Africa & 10 \\
\hline Otway Group & 112 & 3.6 & 148.7 & -48.9 & 181.3 & -73.3 & Australia & 11 \\
\hline Rajmahal Traps & 116 & 6 & 117.0 & -7.0 & 185.6 & -71.8 & India & 12 \\
\hline White Mountains & 122 & 6.9 & 187.4 & 71.9 & 168.6 & -77.1 & North America & 13 \\
\hline Monteregian Hills & 124 & 2 & 191.0 & 73.0 & 171.8 & -74.9 & North America & 14 \\
\hline Newfoundland dikes & 129 & 4 & 207.0 & 71.0 & 164.7 & -68.4 & North America & 15 \\
\hline Kaoka lavas, Namibia & 130 & $3.9+$ & 86.6 & -48.3 & 177.0 & -70.4 & Africa & 16 \\
\hline Kimberlite pole 2 & 130 & 9.7 & 89.9 & -47.6 & 175.0 & -68.1 & Africa & 5 \\
\hline
\end{tabular}

Ages in mega annum. Continent is that from which pole was transferred. See Table A3 for Euler poles for transferring poles. See Tables 1 and 2 for explanations of other listed parameters. Source: 1 , Vandamme et al. [1991]; 2, calculated by McElhinny and Cowley [1978] from data of Andriamirado [1971]; 3, Storetvedt et al. [1979]; 4, Shive and Frerichs [1974]; 5, Hargraves [1989]; 6, Schult et al. [1981]; 7, Ressetar et al. [1981]; 8, Robertson [1963]; 9, Globerman and Irving [1988]; 10, Gough and Opdyke [1963]; 11, Idnurm [1985]; 12, Klootwijk [1971] with age of Baksi [1986]; 13, Van Fossen and Kent [1992]; 14, Foster and Symons [1979]; 15, LaPointe [1979]; 16, Gideskehaug et al. [1975].

* Calculated from their 31 site mean VGPs.

$\dagger A_{95}$ Conservatively estimated as the major axis of the confidence ellipse. 
Irving, 1988; Van Fossen and Kent, 1992], and India [Besse and Courtillot, 1988, 1991]. The Cretaceous paleomagnetic data set for Australia is reviewed here. Only poles with welldefined means $\left(A_{95}\right.$ less than $\left.10^{\circ}\right)$ are accepted.

The Cretaceous APWP for Africa has been analyzed by Hargraves [1989]. In his choice of 10 poles, ranging in age from about 130 to $75 \mathrm{Ma}$, which met his selection criteria, two results (Lupata Lavas, Mlanje Massif) were deemed marginally acceptable but retained because they filled a temporal gap (110-120 Ma). The Mlanje Massif pole is rejected for this study because it is based on only eight samples, its $A_{95}$ exceeds $10^{\circ}$, and poles of this age are available from other continents. The remaining nine poles are accepted (Table A1). Besse and Courtillot [1991] used the same African data for this time period as Hargraves [1989], but the data were combined somewhat differently. Besse and Courtillot used six separate poles from Madagascar from the original work by Andriamirado [1971] while Hargraves [1989] (and the present study) used the two mean poles of McElhinny and Cowley [1978] recalculated from the two age groups of the data. Besse and Courtillot also combined the Mlanje Massif and Lupata lavas poles into a single pole.

The North American Cretaceous stillstand, as identified by Globerman and Irving [1988] and updated by Van Fossen and Kent [1992], is based on five poles which range in age from approximately $129 \mathrm{Ma}$ to $88 \mathrm{Ma}$. These poles form a cluster in North American coordinates, implying no significant apparent polar wander of North America during this interval. One of these results, the Arkansas intrusions pole of Globerman and Irving [1988], is a combined average based on five sites from the circa $88 \mathrm{Ma}$ Granite Mountain intrusion and 19 sites from the circa 100 Ma Magnet Cove plus Potash Sulfur Springs intrusions. Given the difference in their age, the two group means represent distinct readings of the magnetic field and are separated for the present study. The circa 100 Ma Magnet Cove (+Potash Sulfur Springs) pole is accepted. The ca $88 \mathrm{Ma}$ Granite Mountain pole groups well with the other Cretaceous stillstand poles but is rejected because the $A_{95}$ exceeds $10^{\circ}$. The post-88 Ma Cretaceous poles from North America are more scattered and, at face value, can either be used to support a continuation of the stillstand (based on the results of Vugteveen et al. [1981], Swenson and McWilliams [1989], and Jolly and Sheriff [1992]) or a sudden jump to the Paleocene pole position (based on the results of Diehl [1991] and Gunderson and Sheriff [1991]). Moreover, these results are all from units within or closely associated with the Cretaceous foreland thrust belt, and some or all are likely to have been rotated. The post-88 Ma North American Cretaceous poles are therefore not included due to this ambiguity. In summary, the five Cretaceous stillstand poles from Van Fossen and Kent [1992], with the above-mentioned treatment of the results of Globerman and Irving [1988], are accepted from North America (Table A1). The differences between Besse and Courtillot's [1991] North American poles and those accepted here are that Besse and Courtillot used: (1) the Mount Ascutney pole of Opdyke and Wensink [1966], which is here superseded by the White Mountains pole of Van Fossen and Kent [1992]; (2) the Isachsen diabase pole of Larochelle and Black [1963] which was rejected by Globerman and Inving [1988] (and in the present study) because $A_{95}$ is greater than $10^{\circ}$; (3) the Magnet Cove pole of Scharon and Hsu [1969] in addition to the Magnet Cove pole of Globerman and Irving [1988] though the latter pole supersedes Scharon and Hsu's pole, which is otherwise rejected because $A_{95}$ is greater than $10^{\circ}$; and (4) the Late
Cretaceous Mesaverde Group [Kilbourne, 1969] and Maudlow Formation [Swenson and McWilliams, 1989] poles, whereas we reject the Late Cretaceous poles from North America because of the above mentioned ambiguity apparent from the recently available studies of rocks of this age.

Only two Cretaceous poles from India, the Rajmahal Traps pole of Klootwijk [1971] and the Deccan Traps pole of Vandamme et al. [1991], have well-constrained ages and characteristic magnetizations. Both were accepted by Besse and Courtillot [1991] for inclusion in their master APWP and are used in the present study. The Rajmahal Traps have an updated age of $116 \mathrm{Ma}$ based on ${ }^{40} \mathrm{Ar} /{ }^{39} \mathrm{Ar}$ [Baksi, 1986] (Table A1).

Four paleomagnetic poles from Cretaceous units have been reported for Australia. In an early study, Robertson [1963] gave a thorough report of paleomagnetic results based on AF and thermal demagnetization and rock magnetic studies from the Mount Dromedary igneous complex with an age of circa 96 Ma [McDougall and Wellman, 1976] (with new decay constants of Steiger and Jäger [1977]). Idnurm [1985] reported results based on progressive AF and thermal demagnetization from volcaniclastic sedimentary rocks of the Otway Basin with an age of approximately $112 \mathrm{Ma}$. We accept these two results for inclusion in the APWP (Table A1).

We reject poles from two other studies of Cretaceous rocks from Australia. Robertson and Hastie [1962] reported results from the circa $98 \mathrm{Ma}$ Cygnet alkaline complex but these early results are based on batch demagnetization at only $7.5 \mathrm{mT}$ and yield a poorly defined mean $\left(A_{95}=10^{\circ}\right)$. Schmidt [1976] reported paleomagnetic results from the Bunbury basalts, listing an age of $90 \mathrm{Ma}$, but the dual polarities observed are unlikely to have been acquired during the Cretaceous Normal Superchron (118 to $84 \mathrm{Ma}$ ). The age of the Bunbury basalts was based on discordant $\mathrm{K}$-Ar results from McDougall and Wellman [1976] with ages ranging from 88 to $105 \mathrm{Ma}$; these authors concluded that their results were affected by argon loss

Table A2. East Antarctic Synthetic Apparent Polar Wander Path

\begin{tabular}{cccccccc}
\hline $\begin{array}{c}\text { Age } \\
\text { Range }\end{array}$ & $\begin{array}{c}\text { Mean } \\
\text { Age }\end{array}$ & $N$ & $k$ & $A_{95}$ & Plon ${ }^{\circ} \mathrm{E}$ & Plat ${ }^{\circ} \mathrm{N}$ & Source \\
\hline Pliocene & 3.5 & 5 & 884 & 2.6 & 320.5 & -86.4 & 1 \\
Miocene & 15 & 5 & 190 & 5.6 & 320.9 & -81.9 & 1 \\
Oligocene* & 35 & 1 & & $4.4 \dagger$ & 345.5 & -77.6 & 2 \\
Paleocene & 62 & 1 & & $4.4 \dagger$ & 14.0 & -79.9 & 2 \\
$65-84$ & 73 & 3 & 331 & 6.8 & 36.4 & -80.6 & 3 \\
$75-94$ & 85 & 5 & 167 & 5.9 & 36.0 & -83.4 & 3 \\
$85-104$ & 93 & 7 & 125 & 5.4 & 130.9 & -86.0 & 3 \\
$95-114$ & 102 & 6 & 255 & 4.2 & 171.8 & -80.3 & 3 \\
$105-124$ & 117 & 4 & 681 & 2.9 & 179.2 & -74.9 & 3 \\
$115-134$ & 125 & 6 & 360 & 3.5 & 173.9 & -71.9 & 3 \\
\hline
\end{tabular}

Ages in mega annum. $N$, number of studies. See Tables 1 and 2 for explanations of other listed parameters. Source: 1, African mean poles of Tauxe et al. [1983], Pliocene pole $=329^{\circ} \mathrm{E} / 86^{\circ} \mathrm{S}$, Miocene pole $=334^{\circ} \mathrm{E} / 81^{\circ} \mathrm{S}$ in African coordinates; 2, African mean poles of Schneider and Kent [1990], Oligocene pole $=4.2^{\circ} \mathrm{E} / 74.6^{\circ} \mathrm{S}$, Paleocene pole $=$ 33. $0^{\circ} \mathrm{E} / 70.1^{\circ} \mathrm{E}$ in African coordinates; 3, mean of transferred poles in Table A1. See Table A3 for Euler poles used to transfer African mean poles into East Antarctic coordinates.

* their pole based on geocentric axial dipole model.

$\dagger A_{95}$ estimated as the major axis of the confidence ellipse. 
Table A3. Euler Poles Used for Transferring Paleomagnetic Poles to East Antarctica

\begin{tabular}{lrrrr}
\hline Continent & $\begin{array}{c}\text { Age } \\
\text { Ma }\end{array}$ & $\begin{array}{c}\text { Latitude } \\
{ }^{N} \mathrm{~N}\end{array}$ & $\begin{array}{c}\text { Longitude } \\
{ }^{\mathrm{E}}\end{array}$ & $\begin{array}{c}\text { Angle, } \\
\mathrm{deg}\end{array}$ \\
\hline New Zealand & 95 & 64.03 & -56.96 & 57.65 \\
India & 65 & 9.62 & 16.39 & -46.72 \\
India & 115 & -1.39 & 9.90 & -80.85 \\
Australia & 96 & 1.00 & 38.00 & -28.30 \\
Australia & 112 & 0.19 & 38.24 & -29.09 \\
Africa & 3.5 & 12.90 & -39.77 & -0.52 \\
Africa & 15 & 11.48 & -53.79 & -2.04 \\
Africa & 35 & 9.76 & -39.52 & -5.38 \\
Africa & 62 & 2.66 & -39.52 & -10.86 \\
Africa & 75 & -2.50 & -40.99 & -14.01 \\
Africa & 80 & -4.63 & -39.74 & -15.96 \\
Africa & 90 & -3.54 & -36.58 & -21.83 \\
Africa & 95 & -4.48 & -34.96 & -24.27 \\
Africa & 112 & -6.49 & -31.50 & -34.31 \\
Africa & 130 & -7.18 & -28.25 & -46.27 \\
North America & 88 & 66.11 & 108.12 & 35.33 \\
North America & 100 & 65.99 & 104.08 & 44.34 \\
North America & 122 & 62.98 & 94.68 & 58.24 \\
North America & 124 & 62.56 & 93.85 & 58.84 \\
North America & 129 & 61.48 & 92.00 & 60.30 \\
\hline
\end{tabular}

Ages according to timescale of Kent and Gradstein [1986]. Rotation parameters are interpolated between the reconstructions from the following sources. New Zealand to MBL, Mayes et al. [1990]; India to Antarctica, Royer and Sandwell [1989] $65 \mathrm{Ma}$ Royer and Coffin [1992] 117 Ma; Australia to Antarctica, Royer and Sandwell [1989]; Africa to Antarctica, Mayes et al. [1990] 3.5 - $35 \mathrm{Ma}$; Royer et al. [1988] 62 - $80 \mathrm{Ma}$; Royer and Coffin [1992] 90 - $130 \mathrm{Ma}$; North America to NW Africa, Pindell et al. [1988]; NW Africa to south Africa derived from NW AfricaSouth America equatorial fit of Pindell et al. [1988] and South Atlantic fit and opening of Rabinowitz and LaBrecque [1979]; Africa to Antarctica, Royer et al. [1988] $88 \mathrm{Ma}$; Royer and Coffin [1992] 100 - 129 Ma.

Interpolations assume constant spreading rate in $\mathrm{K}$ quiet zone; negative rotation angles are clockwise.

and only supported an age of at least $90 \mathrm{Ma}$. The Bunbury basalts are underlain by Upper Jurassic strata and overlain by Lower Cretaceous strata [Veevers, 1984; Playford et al., 1976]. Veevers [1984] considers the emplacement of the Bunbury basalts to be related to the initiation of seafloor spreading between Greater India and Australia at about $128 \mathrm{Ma}$ ( 132 Ma using timescale of Kent and Gradstein, 1986). Davies et al. [1989] and Storey et al. [1992] consider the Bunbury basalts to be related to the inception of the mantle plume responsible for the Early Cretaceous Naturaliste Plateau, Rajmahal Traps, and Kerguelen Plateau, beginning at around 120-130 Ma. It therefore seems likely that the mixed polarity magnetizations reported for the Bunbury basalts were acquired during emplacement in the Early Cretaceous, before the onset of the Cretaceous Normal Superchron (118 Ma). Also, a number of paleomagnetic results from Australia have been reported in older rocks, apparently remagnetized during the midCretaceous [Schmidt and Embleton, 1981; Schmidt, 1976], but the magnetization age is only inferred by the general similarity with the Cretaceous poles. These remagnetization poles are not suitable for inclusion in the APWP.

The Cenozoic portion of the East Antarctic APWP is in- cluded for completeness and is based on the African Paleocene and Oligocene poles of Schneider and Kent [1990] and the African Pliocene and Miocene mean poles of Tauxe et al. [1983] (Table A2).

The North American poles were transferred to northwestern Africa using the reconstructions of Pindell et al. [1988]. Rotation parameters for opening in the Benue Trough between $136 \mathrm{Ma}$ and $84 \mathrm{Ma}$ (northwestern Africa to southern Africa) were derived from the equatorial fit of northwestern Africa and South America of Pindell et al. [1988] and the South Atlantic fit and opening of Rabinowitz and LaBrecque [1979] (following the model of Pindell et al. [1988]). The North American poles, as well as the African poles, were then transferred from southern Africa to East Antarctica using the reconstructions of Royer et al. [1988] and Royer and Coffin [1992]. Australian poles were transferred using poles of rotation interpolated from the reconstructions of Royer and Sandwell [1989], and the Indian poles were transferred using the reconstructions of Royer and Coffin [1992]. The interpolations assume a constant spreading rate through the Cretaceous Quiet Zone. The timescale used was that of Kent and Gradstein [1986]. The interpolated rotation poles are listed in Table A3.

Most of the African poles are from southern Africa. The northern African poles are either younger than the opening of the Benue Trough or in the case of the two Wadi Natash, Egypt (circa $95 \mathrm{Ma}$ ) poles there is less than $1^{\circ}$ of rotation in the model. It is unclear how the model applies to Egypt, at the pivot of the opening wedge. Therefore no correction for extension in the Benue Trough has been applied to the Wadi Natash poles.

Acknowledgments. We would like to thank SPRITE members Sam Mukasa and Dave Palais of the University of Michigan, Bob Pankhurst and Bryan Storey of the British Antarctic Survey (BAS), and John Bradshaw and Steve Weaver of the University of Canterbury for their contributions to this research and permission to use their unpublished data. We also thank mountaineers Pete Cleary and Andy Harris of the New Zealand Antarctic Research Program (NZARP; now NZAP) and Damo Carroll of BAS for their expert guiding in the field and assistance in sample collection; Twin Otter pilot Paul Robertson and air mechanic Alan Hopkins of BAS for safely delivering us to distant outcrops; U.S. Navy Antarctic Development Squadron VXE6 for LC-130 support; the U.S. Office of Polar Programs and Antarctic Support Associates for logistical support; and NZARP and the personnel of Scott Base for field support and base accommodations. The first author would also like to thank Walter Pitman and Steve Cande for helpful discussions regarding the global reconstructions. We thank Lisa Gahagan at the Institute for Geophysics, University of Texas at Austin for help with the Antarctic reconstruction in Figure 16. Thanks to Myrl Beck, Karl Kellogg, Russell Burmester, and an anonymous reviewer for thoughtful reviews and comments that helped improve this paper. This research was supported by NSF Office of Polar Programs grants DPP 8916470 (D. V. K.) and DPP 8917127 (I. W. D. D.). Lamont-Doherty contribution number 5204.

\section{References}

Adams, C. J., Geochronological studies of the Swanson Formation of Marie Byrd Land, West Antarctica and correlation with northern Victoria Land, East Antarctica, and South Island, New Zealand, N. Z J. Geol. Geophys., 29, 345-358, 1986.

Adams, C. J., Geochronology of granite terranes in the Ford Ranges, Marie Byrd Land, West Antarctica, N. Z. J. Geol. Geophys., 30, 51$72,1987$.

Adams, R. D., Dispersion-wave studies in Antarctica, in Antarctic Geology and Geophysics, edited by R. J. Adie, pp. 473-480, Universitetsforlaget, Oslo, 1972. 
Andriamirado, C.R.A., Recherches paléomagnétiques sur Madagascar. Resultats et interprétations dans le cadre de la dislocation de la partie occidentale du Gondwana, Ph.D. thesis, 350 pp., Univ. of Strasbourg, Strasbourg, France, 1971.

Baksi, A. K., ${ }^{40} \mathrm{Ar} /{ }^{39} \mathrm{Ar}$ incremental heating study of whole-rock samples from the Rajmahal and Bengal traps, eastern India (abstract), Terra Cognita, 6, 161, 1986.

Barley, M. E., S. D. Weaver, and J. R. de Laeter, Strontium isotope composition and geochronology of intermediate-silicic volcanics, Mount Somers and Banks Peninsula, New Zealand, N. Z. J. Geol. Geophys., 31, 197-206, 1988.

Barrett, P. J., Oligocene sequence cored at CIROS-1, western McMurdo Sound, N.Z Antarct. Rec., 7 (3), 1-7, 1987.

Behrendt, J. C., and A. Cooper, Evidence of rapid Cenozoic uplift of the shoulder escarpment of the Cenozoic West Antarctic rift system and a speculation on possible climate forcing, Geology, 19, 315-319, 1991.

Bentley, C. R., Configuration and structure of the subglacial crust, in The Geology of Antarctica, edited by R. J. Tingey, pp. 335-364, Clarendon, Oxford, 1991.

Bentley, C. R., A. P. Crary, N. A. Ostenso, and E. C. Thiel, Structure of West Antarctica, Science, 131, 131-136, 1960.

Besse, J., and V. Courtillot, Paleogeographic maps of the continents bordering the Indian Ocean since the Early Jurassic, J. Geophys. Res., 93, 11791-11808. 1988.

Besse, J., and V. Courtillot, Revised and synthetic apparent polar wander paths of the African, Eurasian, North American and Indian plates, and true polar wander since $200 \mathrm{Ma}$, J. Geophys. Res., 96 , 4029-4050, 1991.

Blank, H. R., R. A. Cooper, R. H. Wheeler, and I. A. G. Willis, Geology of the Koettlitz-Blue Glacier region, southern Victoria Land, Antarctica, Trans. R. Soc. N. Z., 2, p. 791, 1963.

Blankenship, D. D., R. E. Bell, S. M. Hodge, J. M. Brozena, J. C. Behrendt, and C. A. Finn, Active volcanism beneath the West Antarctic ice sheet and implications for ice-sheet stability, Nature, 361, 526-529, 1993.

Boudette, E. L., R. F. Marvin, and C. E. Hedge, Biotitie, potassiumfeldspar and whole-rock ages of adamellite, Clark Mountains, west Antarctica, U.S. Geol. Surv. Prof. Pap.,550-D, D-190-94, 1966.

Bradshaw, J. D., Cretaceous dispersion of Gondwana: Continental and oceanic spreading in the south-west Pacific-Antarctic sector, in Geological Evolution of Antarctica, edited by M. R. A. Thomson, J. A. Crame, and J. W. Thomson, pp. 581-585, Cambridge University Press, New York, 1991.

Bradshaw, J. D., P. B. Andrews, and B. D. Field, Swanson Formation and related rocks of Marie Byrd Land and a comparison with the Robertson Bay Group of northern Victoria Land, in Antarctic Earth Science, edited by R. L. Oliver, P. R. James, and J. B. Jago, pp. 274 279, Australian Academy of Science, Canberra, New South Wales, 1983.

Burk, K., and J. F. Dewey, Two plates in Africa during the Cretaceous?, Nature, 249, 313-316, 1974.

Cooper, A. K., F. J. Davey, and J. C. Behrendt, Seismic stratigraphy and structure of the Victoria Land Basin, western Ross Sea, Antarctica, in The Antarctic Continental Margin: Geology and Geophysics of the Western Ross Sea, Earth Sci. Ser., vol. 5B, edited by A. K. Cooper and F. J. Davey, pp. 27-65, Circum-Pacific Council for Energy and Mineral Resources, Houston, Tex., 1987.

Cooper, A.K., F.J. Davey, and K. Hinz, Crustal extension and origin of sedimentary basins beneath the Ross Sea and Ross Ice Shelf, in Geological Evolution of Antarctica, edited by M. R. A. Thomson, J. A. Crame, and J. W. Thomson, pp. 285-291, Cambridge University Press, New York, 1991.

Dalziel, I. W. D., and D. H. Elliot, West Antarctica: Problem child of Gondwanaland, Tectonics, 1, 3-19, 1982.

Davey, F. J., K. Hinz, and H. Schroeder, Sedimentary basins of the Ross Sea region, in Antarctic Earth Science, edited by R. L. Oliver, P. R. James, and J. B. Jago, pp. 533-538, Australian Academy of Science, Canberra, New South Wales, 1983.

Davies, H. L., et al., Basalt basement from the Kerguelen Plateau and the trail of a Dupal plume, Contrib. Mineral. Petrol., 103, 457-469, 1989.

Delisle, G., Results of paleomagnetic investigations in northern Victoria Land, Antarctica, in Antarctic Earth Science, edited by R. L. Oliver, P. R. James, and J. B. Jago, pp. 146-149, Australian Academy of Science, Canberra, New South Wales, 1983.

Delisle, G., and K. Fromm, Paleomagnetic investigation of Ferrar Supergroup rocks, North Victoria Land, Geol. Jahrb., B 41, 41-55, 1984.

Delisle, G., and K. Fromm, Further evidence for a Cretaceous thermal event in North Victoria Land, Geol Jahrb., E 38, 143-151, 1989.

Diehl, J. F., The Elkhorn Mountains revisited: New data for the Late Cretaceous paleomagnetic field of North America, J. Geophys. Res., 96, 9887-9894, 1991.

DiVenere, V. J., J. D. Bradshaw, S. D. Weaver, D. G. Palais, R. J. Pankhurst, and B. C. Storey, Geological investigations in eastern Marie Byrd Land, West Antarctica, Antarct. J. U.S., 28, 5-6, 1993.

Duncan, R. A., Hotspots in the southern oceans - An absolute frame of reference for motion of the Gondwana continents, Tectonophysics, 74, 29-42, 1981.

Duncan, R. A., and M. A. Richards, Hotspots, mantle plumes, flood basalts, and true polar wander, Rev. Geophys., 29, 31-50, 1991.

Fisher, R. A., Dispersion on a sphere, Proc. R. Soc. London Ser. A, 217. 295-305, 1953.

Fitzgerald, P. G., The Transantarctic Mountains of Southern Victoria Land: The application of apatite fission track analysis to a rift shoulder uplift, Tectonics, 11, 634-662, 1992.

Ford, A. B., and P. J. Barrett, Basement rocks of the south-central Ross Sea, Site 270, DSDP Leg 28, Initial Rep. Deep Sea Drill. Proj., 28, 861-868, 1975.

Foster, J., and D. T. A. Symons, Defining a paleomagnetic polarity pattern in the Monteregian intrusives, Can. J. Earth Sci., 16, 1716-1725, 1979.

Gideskehaug, A., K. M. Creer, and J. G. Mitchell, Paleomagnetism and $\mathrm{K}$-Ar ages of the South-West African basalts and their bearing on the time of initial rifting of the South Atlantic Ocean, Geophys. J. $R$. Astron. Soc., 42, 1-20, 1975.

Globerman, B. R., and E. Irving, Mid-Cretaceous paleomagnetic field for North America: restudy of $100 \mathrm{Ma}$ intrusive rocks from Arkansas, J. Geophys. Res., 93, 11721-11733, 1988.

Gordon, R. G., and A. Cox, Paleomagnetic test of the Early Tertiary plate circuit between the Pacific basin plates and the Indian plate, $J$. Geophys. Res., 85, 6534-6546, 1980.

Gough, D. I., and N. D. Opdyke, The paleomagnetism of the Lupata alkaline volcanics, Geophys. J. R. Astron. Soc., 7, 457-468, 1963.

Grindley, G. W., and F. J. Davey, The Reconstruction of New Zealand, Australia, and Antarctica, in Antarctic Geoscience, edited by C. Craddock, pp. 15-29, University of Wisconsin Press, Madison, 1982.

Grindley, G. W., and P. J. Oliver, Paleomagnetism of Cretaceous volcanic rocks from Marie Byrd Land, in Antarctic Earth Science, edited by R. L. Oliver, P. R. James, and J. B. Jago, Pp. 573-578, Australian Academy of Science, Canberra, New South Wales, 1983.

Grunow, A. M., Paleomagnetic data from the Antarctic Peninsula and their implication for opening of the Weddell Sea, J. Geophys. Res., 98, 13815-13833, 1993.

Grunow, A. M., I. W. D. Dalziel, and D. V. Kent, Ellsworth-Whitmore Mountains crustal block, western Antarctica: New paleomagnetic results and their tectonic significance, in Gondwana Six: Structure, Tectonics, and Geophysics, Geophys. Monogr. Ser., vol. 40, edited by G. D. McKenzie, pp. 161-171, AGU, Washington, D. C., 1987a.

Grunow, A. M., D. V. Kent, and I. W. D. Dalziel, Mesozoic evolution of West Antarctica and Weddell Sea Basin: New paleomagnetic constraints, Earth and Planet. Sci. Lett., 86, 16-26, $1987 \mathrm{~b}$.

Grunow, A. M., D. V. Kent, and I. W. D. Dalziel, New paleomagnetic data from Thurston Island: Implications for the tectonics of West Antarctica and Weddell Sea Opening, J. Geophys. Res., 96, 1793517954, 1991.

Gunderson, J. A., and S. D. Sheriff, A new Late Cretaceous paleomagnetic pole from the Adel Mountains, west central Montana, J. Geophys. Res., 96, 317-326, 1991. 
Halpern, M., Ages of Antarctic and Argentine rocks bearing on continental drift, Earth Planet. Sci. Lett., S, 159-167, 1968.

Halpern, M., Rb-Sr total-rock and mineral ages from the Marguerite Bay area, Kohler Range and Fosdick Mountains, in Antarctic Geology and Geophysics, edited by R. J. Adie, Pp. 197-204, Universitetsforlaget, Oslo, 1972.

Hargraves, R. B., Paleomagnetism of Mesozoic kimberlites in Southern Africa and the Cretaceous apparent polar wander curve for Africa, J. Geophys. Res., 94, 1851-1866, 1989.

Harland, W. B., A. V. Cox, P. G. Llewellyn, C. A. G. Pickton, A. G. Smith, and R. Walters, A Geologic Time Scale, 131 pp., Cambridge University Press, New York, 1982.

Hayes, D. E., and L. A. Frakes, General synthesis, Deep Sea Drilling Project Leg 28, Initial Rep. Deep Sea Drill. Proj., 28, 919-942, 1975.

Hayes, D. E., et al., Sites 270, 271, 272, Initial Rep. Deep Sea Drill. Proj., 28, Washington (U.S. Government Printing Office), 211-334, 1975.

Hinz, K., and M. Block, Results of geophysical investigations in the Weddell Sea and in the Ross Sea, Antarctica, Proceedings of 11th World Petroleum Congress, (London) 1983, vol. 2,_Geology Exploration Reserves, pp. 79-81, John Wiley, New York, 1984.

Hole, M. J., and W. E. LeMasurier, Tectonic controls on the geochemical composition of Cenozoic mafic alkaline volcanic rocks from West Antarctica, Contrib. Mineral. Petrol., in press, 1994.

Idnurm, M., Late Mesozoic and Cenozoic palaeomagnetism of Australia, I, A redetermined apparent polar wander path, Geophys. J. R. Astron. Soc., 83, 399-418, 1985.

Irving, E., and G. A. Irving, Apparent polar wander paths from the Carboniferous through Cenozoic and the assembly of Gondwana, Geophys. Surv., 5, 141-188, 1982.

Inokuchi, H., and F. Heider, Paleolatitude of the southern Kerguelen Plateau inferred from the paleomagnetic study of Upper Cretaceous basalts, Ocean Drill. Program Sci Results, 120, 89-96, 1992.

Jolly, A. D., and S. D. Sheriff, Paleomagnetic study of thrust-sheet motion along the Rocky Mountain front in Montana, Geol. Soc. Am. Bull., 104, 779-785, 1992.

Kellogg, K. S., Paleomagnetic evidence for oroclinal bending of the southern Antarctic Peninsula, Geol. Soc. Am. Bull., 91, 414-420, 1980.

Kellogg, K. S., A paleomagnetic investigation of rocks from the Ohio Range and the Dry Valleys, Transantarctic Mountains, Antarctica, $N$. Z J. Geol, Geophys., 31, 77-85, 1988.

Kellogg, K. S., and R. L. Reynolds, Paleomagnetic results from the Lassiter Coast, Antaretica, and a test for oroclinal bending of the Antarctic Peninsula, J. Geophys. Res., 83, 2293-2298, 1978.

Kellogg, K. S., and P. D. Rowley, Structural geology and tectonics of the Orville Coast region, southern Antarctic Peninsula, Antarctica, U.S. Geol. Surv. Prof. Pap., 1498, 25 pp., 1989.

Kent, D. V., and F. M. Gradstein, A Jurassic to recent chronology, in The Geology of North America, vol. M, The Westem Atlantic Region, edited by P. R. Bogt and B. E. Tucholke, Pp. 45-50, Geological Society of America, Boulder, Col., 1986.

Kilbourne, D. E., Paleomagnetism of some rocks from the Mesaverde Group, south-western Wyoming and north-eastern Utah, Geol. Soc. Am. Bull., 80, 2069-2074, 1969.

Kirschvink, J. L., The least-squares line and plane and the analysis of paleomagnetic data, Geophys. J. R. Astron. Soc., 62, 699-718, 1980.

Klootwijk, C. T., Palaeomagnetism of the upper Gondwana Rajmahal Traps, Northeast India, Tectonophysics, 12, 449-467, 1971.

Langel, R. A., International Geomagnetic Reference Field, 1991 revision: Intemational Association of Geomagnetism and Aeronomy (IAGA) Division V, Working Group 8: Analysis of the main field and secular variation, Phys. Earth Planet. Inter., 70, 1-6, 1992.

LaPointe, P. L., Paleomagnetism of the Notre Dame lamprophyre dikes, Newfoundland, and the opening of the North Atlantic Ocean, Can. J. Earth Sci., 16, 1823-1831, 1979.

Larochelle, A., and R. R. Black, An application of paleomagnetism in estimating the age of rocks, Nature, 198, 1260-1262, 1963.

Lawver, L. A., I. W. D. Dalziel, and D. T. Sandwell, Antarctic Plate:
Tectonics from a gravity anomaly and infrared satellite image, GSA Today, 3, 117-122, 1993.

LeMasurier, W. E., The Cenozoic West Antarctic rift system and its associated volcanic and structural features, Geol. Soc. Am. Abstr. Programs, 10, 443, 1978.

LeMasurier, W. E., and D. C. Rex, Rates of uplift and the scale of ice level instabilities recorded by volcanic rocks in Marie Byrd Land, West Antarctica, in Antarctic Earth Science, edited by R. L. Oliver, P. R. James, and J. B. Jago, pp. 663-670, Australian Academy of Science, Canberra, New South Wales, 1983.

LeMasurier, W. E., and D. C. Rex, The Marie Byrd Land volcanic province and its relation to the Cainozoic West Antarctic rift system, in The Geology of Antarctica, edited by R. J. Tingey, pp. 249-284, Clarendon, Oxford, 1991.

Longshaw, S. K., and D. H. Griffiths, A palaeomagnetic study of Jurassic rocks from the Antarctic Peninsula and its implications, $J$. Geol. Soc. London, 140, 945-954, 1983.

Mason, B., and S. R. Taylor, High-grade basement gneisses and granitoids in Westland, New Zealand, J. R. Soc. N. Z., 17, 115-138, 1987.

Mayes, C. L., L. A. Lawver, and D. T. Sandwell, Tectonic history and new isochron chart of the South Pacific, J. Geophys. Res., 95, 85438567, 1990.

McDougall, I., and P. Wellman, Potassium-argon ages for some Australian Mesozoic igneous rocks, Aust. J. Earth Sci., 23, 1-9, 1976.

McElhinny, M. W., and J. A. Cowley, Paleomagnetic directions and pole positions, XV Pole numbers $15 / 1$ to $15 / 232$, Geophys. J. R. Astron. Soc., 52, 259-276, 1978.

McFadden, P. L., and F. J. Lowes, The discrimination of mean directions drawn from Fisher distributions, Geophys. J. R. Astron. Soc., 67, 1933, 1981.

McFadden, P. L., and A. B. Reid, Analysis of paleomagnetic inclination data, Geophys. J. R. Astron. Soc., 69, 307-319, 1982.

McIntosh, W. C., P. R. Kyle, E. M. Cherry, and H. C. Noltimier, Paleomagnetic results from the Kirkpatrick Basalt Group, Victoria Land, Antarct. J. U.S., 17, 20-22, 1982.

Molnar, P., and J. Stock, Relative motions of hotspots in the Pacific, Atlantic and Indian Oceans since late Cretaceous time, Nature, 327, 587-591, 1987.

Norton, I. O., and J. G. Sclater, A model for the evolution of the Indian Ocean and the breakup of Gondwanaland, J. Geophys. Res., 84, 6803-6830, 1979

Oliver, P. J., T. C. Mummé, G. W. Grindley, and P. Vella, Palaeomagnetism of the Upper Cretaceous Mt Somers Volcanics, Canterbury, New Zealand, N. Z. J. Geol. Geophys., 22, 199-212, 1979.

Opdyke, N. D., and H. Wensink, Paleomagnetism of rocks from the White Mountain plutonic-volcanic series in New Hampshire and Vermont, J. Geophys. Res., 71, 3045-3051, 1966.

Palais, D. G., S. B. Mukasa, and S. D. Weaver, U-Pb and ${ }^{40} \mathrm{Ar} /{ }^{39} \mathrm{Ar}$ geochronology for plutons along the Ruppert and Hobbs Coasts, Marie Byrd Land, West Antarctica: Evidence for rapid transition from arc to rift-related magmatism (abstract), Eos, Trans. AGU, 74 (16), Spring Meeting suppl., 123, 1993.

Patriat, P., Reconstruction de l'évolution du système de dorsales de l'Océan Indien par les méthodes de la cinématique des plaques, thèse d'état, 308 pp., Univ. Paris VII, 1983.

Patriat, P., J Ségoufin, J. Goslin, and P. Beauzart, Relative position of Africa and Antarctica in the Upper Cretaceous: Evidence for non stationary behaviour of fracture zones, Earth Planet. Sci. Lett., 75, 204-214, 1985.

Pindell, J., and J. F. Dewey, Permo-Triassic reconstruction of Western Pangea and the evolution of the Gulf of Mexico/Caribbean region, Tectonics, 1, 179-211, 1982.

Pindell, J. L., S. C. Cande, W. C. Pitman III, D. B. Rowley, J. F. Dewey, J. LaBrecque, and W. Haxby, A plate-kinematic framework for models of Caribbean evolution, Tectonophysics, 155, 121-138, 1988.

Playford, P. E., A. E. Cockbain, and G. H. Low, Geology of the Perth Basin, Western Australia, Bull. Geol. Surv. West Aust., 124, 311 pp., 1976. 
Rabinowitz, P. D., and J. LaBrecque, The Mesozoic south Atlantic Ocean and evolution of its continental margins, J. Geophys, Res., 84, 5973-6002, 1979.

Ressetar, R., A. E. M. Nairn, and J. R. Monrad, Two phases of Cretaceous-Tertiary magmatism in the eastern desert of Egypt: Paleomagnetic, chemical and K-Ar evidence, Tectonophysics, 73, 169-193, 1981.

Robertson, W. A., Paleomagnetism of some Mesozoic intrusives and tuffs from eastern, Australia, J. Geophys. Res., 68, 2299-2312, 1963.

Robertson, W. A., and L. Hastie, A palaeomagnetic study of the Cygnet Alkaline Complex of Tasmania, Aust. J. Earth Sci., 8, 259-268, 1962.

Royer, J.-Y., and M. F. Coffin, Jurassic to Eocene plate tectonic reconstructions in the Kerguelen Plateau region, Ocean Drill. Program, 120, 917-928, 1992.

Royer, J.-Y., and D. T. Sandwell, Evolution of the Eastern Indian Ocean since the Late Cretaceous: Constraints from Geosat altimetry, $J$. Geophys. Res., 94, 13755-13782, 1989.

Royer, J.-Y., P. Patriat, H. Bergh, and C. R. Scotese, Evolution of the Southwest Indian Ridge from the Late Cretaceous (anomaly 34) to the middle Eocene (anomaly 20), Tectonophysics, 155, 235-260, 1988.

Sakai, H., and B. Keating, Paleomagnetism of Leg 119 - holes 737A, 738C, 745B, and 746A, Ocean Drill. Program, 119, 751-770, 1991.

Sandwell, D. T., and D. C. McAdoo, Marine gravity of the southern ocean and Antarctic margin from Geosat, J. Geophys. Res., 93, 10389-10396, 1988.

Scharnberger, C. K., and L. Scharon, Paleomagnetism and plate tectonics of Antarctica, in Antarctic Geology and Geophysics, edited by R. J. Adie, pp. 843-847, Universitetsforlaget, Oslo, 1972.

Scharon, L., and I. C. Hsu, Paleomagnetic investigation of some Arkansas alkalic igneous rocks, J. Geophys. Res., 74, 2774-2779, 1969.

Schmidt, P. W., A new palaeomagnetic investigation of Mesozoic igneous rocks in Australia, Teconophysics, 33, 1-33, 1976.

Schmidt, P. W., and B. J. J. Embleton, Magnetic overprinting in southeastern Australia and the thermal history of its rifted margin, $J$. Geophys. Res., 86, 3998-4008, 1981.

Schmierer, K., and R. Burmester, Paleomagnetic Results from the Cambro-Ordovician Bowers Supergroup, northern Victoria Land, Antarctica, in Geological Investigations in Northern Victoria Land, Antarct. Res. Ser., vol. 46, edited by E. Stump, pp.69-90, AGU, Washington, D. C., 1986.

Schneider, D. A., and D. V. Kent, Testing models of the Tertiary paleomagnetic field, Earth Planet. Sci. Lett., 101, 260-271, 1990.

Schult, A., A. G. Hussain, and H. C. Soffel, Paleomagnetism of Upper Cretaceous volcanics and Nubian sandstones of Wadi Natash, S. E. Egypt and implication for the polar wander path for Africa in the Mesozoic, J. Geophys., 50, 16-22, 1981.

Ségoufin, J., Morphologie et structure du canal du Mozambique, thèse d'état, 236 pp., Univ. Louis Pasteur, Strasbourg, France, 1980.

Ségoufin, J., and P. Patriat, Existence d'anomalies mésozoic dans le bassin de Somalie. Implications pour les relations AfriqueAntarctique-Madagascar, C. R. Acad. Sc., 291, 85-88, 1980.

Shive, P. N., and W. E. Frerichs, Paleomagnetism of the Niobrara Formation in Wyoming, Colorado, and Kansas, J. Geophys. Res., 79, 3001-3007, 1974.

Spörli, K. B., and C. Craddock, Geology of the Ruppert Coast, Marie Byrd Land, Antarctica, in Gondwana Five, edited by M. M. Cresswell, and P. Vella, pp. 243-250, A. A. Balkema, Rotterdam, Netherlands, 1981.

SPRITE Group, and C. G. Boyer, The southern rim of the Pacific Ocean: Preliminary geologic report of the Amundsen SeaBellingshousen Sea cruise of the Polar Sea, 12 February-21 March 1992, Antarct. J. U.S., 27, 11-14, 1992.

Steiger, R. H., and E. Jäger, Subcommission on Geology: Convention on the use of decay constants in geo- and cosmo- chronology, Earth Planet. Sci. Lett., 36, 359-362, 1977.

Stern, T. A., and U. S. ten Brink, Flexural uplift of the Transantarctic Mountains, J. Geophys. Res., 94, 10,315-10,330, 1989.

Storetvedt, K. M., A. M. Vage, S. Aase, and R. Lovlie, Paleomagnetism and the early magmatic history of Fuerteventura (Canary Island), J. Geophys., 46, 319-334, 1979.

Storey, B. C., The crustal blocks of West Antarctica within Gondwana: reconstruction and break-up model, in Geological Evolution of Antarctica, edited by M. R. A. Thomson, J. A. Crame, and J. W. Thomson, pp. 587-592, Cambridge University Press, New York, 1991.

Storey, M., et al., Lower Cretaceous volcanic rocks on continental margins and their relationship to the Kerguelen Plateau, Proc. Ocean Drill. Program Sci. Results, vol. 120, 33-47, 1992.

Stump, E. S., and P. G. Fitzgerald, Episodic uplift of the Transantarctic Mountains, Geology, 20, 161-164, 1992.

Swenson, P., and M. McWilliams, Paleomagnetic results from the Upper Cretaceous Maudlow and Livingston formations, southwest Montana, Geophys. Res. Lett., 16, 669-672, 1989.

Tauxe, L., J. Besse, and J. LaBrecque, Palaeolatitudes from DSDP Leg 73 sediment cores: implications for the apparent polar wander path for Africa during the late Mesozoic and Cenozoic, Geophys. J. R. Astron. Soc., 73, 315-324, 1983.

ten Brink, U. S., S. Bannister, B. C. Beaudoin, and T. A. Stern, Geophysical investigations of the tectonic boundary between East and West Antarctica, Science, 261, 45-50, 1993.

Valencio, D. A., J. E. Mendîa, and J. F. Vilas, Palaeomagnetism and KAr age of Mesozoic and Cenozoic igneous rocks from Antarctica, Earth Planet. Sci. Lett., 45, 61-68, 1979.

Vandamme, D., V. Courtillot, J. Besse, and R. Montigny, Paleomagnetism and age determinations of the Deccan Traps (India): Results of a Nagpur-Bombay traverse and review of earlier work, Rev. Geophys., 29, 159-190, 1991.

Van Fossen, M. C., and D. V. Kent, Paleomagnetism of 122 Ma plutons in New England and the Mid-Cretaceous paleomagnetic field in North America: True polar wander or large-scale differential mantle motion?, J. Geophys. Res., 97, 19651-19661_ 1992.

Veevers, J. J. (Ed.), Phanerozoic Earth History of Australia, 418 pp., Clarendon, Oxford, 1984.

Vugteveen, R. W., A. E. Barnes, and R. F. Butler, Paleomagnetism of the Roskruge and Gringo Gulch volcanics, southeast Arizona, $J$. Geophys. Res., 86, 4021-4028, 1981.

Wade, F. A., and J. R. Wilbanks, Geology of Marie Byrd and Ellsworth Lands, in Antarctic Geology and Geophysics, edited by R. J. Adie, pp. 207-214, Universitetsforlaget, Oslo, 1972.

Watts, D. R., and A. M. Bramall, Palaeomagnetic evidence for a displaced terrain in Western Antarctica, Nature, 293, 638-641, 1981.

Watts, D. R., G. C. Watts, and A. M. Bramall, Cretaceous and Early Tertiary paleomagnetic results from the Antarctic Peninsula, Tectonics, 3, 333-346, 1984.

Weaver, S. D., C. J. Adams, R. J. Pankhurst, and I. L. Gibson, Granites of Edward VII Peninsula, Marie Byrd Land: Anorogenic magmatism related to Antarctic-New Zealand rifting, Trans. R. Soc. Edinburgh Earth Sci., 83, 281-290, 1992.

Wilch, T. I., D. R. Lux, G. H. Denton, and W. C. McIntosh, Minimal Pliocene-Pleistocene uplift of the Dry Valleys sector of the Transantarctic Mountains: A key parameter in ice-sheet reconstructions, Geology, 21, 841-844, 1993.

Wilson, T. J., Mesozoic and Cenozoic kinematic evolution of the Transantarctic Mountains, in Recent Progress in Antarctic Earth Science, edited by Y. Yoshida, K. Kaminuma, and K. Shiraishi, pp. 303-314, Terra Scientific, Tokyo, 1993.

Zijderveld, J. D. A., AC demagnetization of rocks: An3alysis of results, in Methods in Paleomagnetism, edited by D. W. Collinson, K. M. Creer, and S. K. Runcorn ,pp. 172-191, Elsevier, New York, 1967.

I. W. D. Dalziel, Institute for Geophysics, University of Texas at Austin, Austin, TX 78759-8435. (email: ian @utig.ig.utexas.edu).

V. J. DiVenere and D. V. Kent, Lamont-Doherty Earth Observatory, P. O. Box 1000, Rt. 9W, Palisades, NY 10964. (sprite@lamont.ldgo.columbia.edu).

(Received November 22, 1993; revised March 14, 1994; accepted March 21, 1994.) 